\title{
Increased N20 Production from Soil Organic Matter Following a Simulated Fall-Freeze-Thaw Cycle: Effects of Fall Urea Addition, Soil Moisture, and History of Manure Applications
}

Sisi Lin ( $\nabla$ slin4@ualberta.ca )

University of Alberta

Guillermo Hernandez-Ramirez

University of Alberta

\section{Research Article}

Keywords: priming effect, nitrous oxide, organic matter, denitrification, freeze, thaw.

Posted Date: May 25th, 2021

DOl: https://doi.org/10.21203/rs.3.rs-545397/v1

License: (c) (i) This work is licensed under a Creative Commons Attribution 4.0 International License.

Read Full License 


\section{Increased $\mathrm{N}_{2} \mathrm{O}$ production from soil organic matter following a simulated fall-freeze-thaw}

2 cycle: Effects of fall urea addition, soil moisture, and history of manure applications

4 Sisi Lin ${ }^{1}$; Guillermo Hernandez-Ramirez ${ }^{1 *}$

5 1. Department of Renewable Resources, University of Alberta

$6 *$ Corresponding author: Guillermo Hernandez Ramirez

7 Address:

8426 Earth Sciences Building, Department of Renewable Resources Department, Faculty of

9 Agricultural Life and Environmental Sciences, University of Alberta

10 Edmonton, AB, Canada T6G 2E3

11 E-mail: ghernand@ualberta.ca

12 Phone: +1-7804922428 


\section{Abstract}

18 Adding nitrogen substrates to soils can induce short-term changes in soil organic matter (SOM)

19 transformations - a response termed the 'priming effect'. However, it is unknown how priming

20 effects on nitrous oxide $\left(\mathrm{N}_{2} \mathrm{O}\right)$ emissions can be altered following a strong freeze-thaw cycle. A

21 mesocosm experiment evaluated two soil managements: with and without history of manure

22 applications. These soils were subjected to three moisture regimes: Low, Medium and High.

23 Apart from the controls, which received no $\mathrm{N}$, we banded ${ }^{15} \mathrm{~N}$-labelled urea into these soils

24 representing a typical fall fertilization, and subsequently simulated a wide fall-freeze-thaw cycle,

25 with temperatures from +2 , to -18 , and finally $+23^{\circ} \mathrm{C}$, respectively. The overall highest $\mathrm{N}_{2} \mathrm{O}$

26 production was observed 1 day after thawing. At that time, measurements of $\mathrm{N}_{2} \mathrm{O}$ site preference

27 indicated that denitrification produced $83 \%$ of the $\mathrm{N}_{2} \mathrm{O}$ flux. Relative to the unamended controls

28 (baseline), adding urea consistently triggered a $24 \%$ greater cumulative $\mathrm{N}_{2} \mathrm{O}$ production

29 specifically originated from SOM following thawing (245 vs. $305 \mu \mathrm{g} \mathrm{N} \mathrm{N}_{2} \mathrm{O} \mathrm{N} \mathrm{kg}^{-1} \mathrm{soil} P=0.022$ ).

30 This substantiates a positive priming of SOM that manifested shortly after the rapid, wet thawing

31 of the soils. Soils having a manure history or higher moisture also exhibited an augmented

32 production of $\mathrm{N}_{2} \mathrm{O}$ from $\mathrm{SOM}\left(P_{\mathrm{S}}<0.01\right)$. Although the overall priming of SOM was positive,

33 two weeks after thawing, negative priming of daily $\mathrm{N}_{2} \mathrm{O}$ fluxes also occurred, but only in soils

34 under High moisture. Besides urea additions, the propensity for primed $\mathrm{N}_{2} \mathrm{O}$ emissions from

35 SOM after thawing was influenced by increasing moisture and earlier manure applications.

36 Key words: priming effect, nitrous oxide, organic matter, denitrification, freeze, thaw. 


\section{Introduction}

38 Nitrous oxide $\left(\mathrm{N}_{2} \mathrm{O}\right)$ is a potent greenhouse gas - with even 300-fold higher global warming

39 potential than carbon dioxide $\left(\mathrm{CO}_{2}\right)$ on mass basis (Parry et al. 2007, Intergovernmental Panel on

40 Climate Change 2013). More than half of the anthropogenic sources of $\mathrm{N}_{2} \mathrm{O}$ are linked to

41 agricultural landscapes (Parry et al. 2007, Intergovernmental Panel on Climate Change 2013,

42 Chai et al. 2020), where manure and synthetic $\mathrm{N}$ fertilizers are recurrently applied (Lin et al.

43 2017, Grant et al. 2020, Thilakarathna et al. 2020). Such N additions not only provide substrates

44 for $\mathrm{N}_{2} \mathrm{O}$ emissions directly, but they can also stimulate mineralization of pre-existing SOM,

45 which would subsequently lead to additional $\mathrm{N}_{2} \mathrm{O}$ emissions indirectly - a response termed the

46 'priming effect' (Thilakarathna and Hernandez-Ramirez 2021). In other words, in the case of

$47 \quad \mathrm{~N}_{2} \mathrm{O}$ emissions from soils, priming consists of the fertilizer-induced $\mathrm{N}_{2} \mathrm{O}$ emissions that originate

48 from $\mathrm{SOM}$ mineralization. In further details, the magnitude and direction of $\mathrm{N}_{2} \mathrm{O}$ priming is a

49 function of the short-term acceleration (positive priming effect) or retardation (negative priming

50 effect) of SOM-derived $\mathrm{N}_{2} \mathrm{O}$ emissions from a soil receiving $\mathrm{N}$ compared to an unamended

51 control as baseline. A comprehensive understanding of $\mathrm{N}_{2} \mathrm{O}$ priming effects can improve

52 quantification, proactive mitigation and ability to predict $\mathrm{N}_{2} \mathrm{O}$ emissions from agricultural soils

53 (Grant et al. 2020).

54 As climate change continues to take place, extreme fluctuations in the weather conditions can

55 occur with increased frequency. Although soil freezing and thawing are already common

56 phenomena in cold regions with relatively high latitude and altitude, the intensity and frequency

57 of freeze-thaw cycles are gradually increasing as a feedback to escalating climate change 
58 (Goldberg et al. 2008, Easterling et al. 2017). This applies to large temperate regions located in

59 North America and Eurasia where annual croplands typically dominate the landscape. Within

60 this context, earlier laboratory and field studies have examined $\mathrm{N}_{2} \mathrm{O}$ emissions taking place over

61 freeze-thaw cycles (Wagner-Riddle et al. 2007, Goldberg et al. 2008, Wolf et al. 2010, Wu et al.

62 2010, Yanai et al. 2011, Abalos et al. 2016). These reports indicate that $\mathrm{N}_{2} \mathrm{O}$ fluxes during spring

63 thaw can typically account for $30-90 \%$ of the annual $\mathrm{N}_{2} \mathrm{O}$ emissions. A recent field study in

64 western Canada found that at least $67 \%$ of the annual $\mathrm{N}_{2} \mathrm{O}$ emissions occurred during the spring

65 thaw in soils that had received liquid manure in the previous fall (Lin et al. 2017, Grant et al.

66 2020). Soil thawing activates $\mathrm{N}_{2} \mathrm{O}$ production not only because of fast increases in ambient

67 temperature but also because of sudden increases in soil water content caused by snow and ice

68 melting (Wolf et al. 2010, Thilakarathna et al. 2020). It has been documented that increased

69 moisture influences $\mathrm{N}_{2} \mathrm{O}$ production by displacing and reducing oxygen availability, which

70 drives a shift towards microbial utilization of nitrate as terminal electron acceptor during

71 denitrification (Davidson 1991, Ruser et al. 2006, Lin and Hernandez-Ramirez 2020).

72 Nevertheless, there is currently a paucity of knowledge on how freeze-thawing can influence the

73 production of $\mathrm{N}_{2} \mathrm{O}$ from $\mathrm{SOM}$ and the associated priming effects caused by labile $\mathrm{N}$ additions.

74 In addition to examining the priming of SOM, there is also a growing interest to assess the

75 underlying processes of $\mathrm{N}_{2} \mathrm{O}$ production. Both nitrification and denitrification contribute to $\mathrm{N}_{2} \mathrm{O}$

76 fluxes from soils (Butterbach-Bahl et al. 2013). However, it is still unclear which of these

77 processes is dominant during peak $\mathrm{N}_{2} \mathrm{O}$ emissions in manured soils (Lin et al. 2017,

78 Thilakarathna et al. 2020). As aforementioned an accelerated biological activity immediately 
79 following thawing can critically deplete $\mathrm{O}_{2}$ concentrations in the soil microsites, and hence it is

80 hypothesized that the contribution of bacterial denitrification to $\mathrm{N}_{2} \mathrm{O}$ production would also

81 increase (Yanai et al. 2011). The ${ }^{15} \mathrm{~N}$ isotope ratios at the central $\left(\alpha ;{ }^{14} \mathrm{~N}-{ }^{15} \mathrm{~N}-\mathrm{O}\right)$ and terminal $(\beta$;

$82{ }^{15} \mathrm{~N}-{ }^{14} \mathrm{~N}-\mathrm{O}$ ) positions within the $\mathrm{N}_{2} \mathrm{O}$ molecule - known as site preference (SP) - can reveal the

83 dominant process contributing to $\mathrm{N}_{2} \mathrm{O}$ production (Toyoda and Yoshida 1999, Toyoda et al.

84 2011, Yamamoto et al. 2017). The difference between $\alpha$ and $\beta$ can be expressed as $\mathrm{SP}=\delta^{15} \mathrm{~N}^{\alpha}$ -

$85 \delta^{15} \mathrm{~N}^{\beta}$ (Toyoda and Yoshida 1999, Yamamoto et al. 2017). When $\mathrm{N}_{2} \mathrm{O}$ fluxes become sufficiently

86 large, this SP analytical approach enables us to examine and apportion the major $\mathrm{N}_{2} \mathrm{O}$ producing

87 pathways (i.e., nitrification vs. bacterial denitrification) (Zimmerman et al. 2011, Daly and

88 Hernandez-Ramirez 2020, Thilakarathna and Hernandez-Ramirez 2021).

89 To address the abovementioned unknowns, we conducted a mesocosm experiment with the aim

90 of investigating $\mathrm{N}_{2} \mathrm{O}$ fluxes and sources (i.e., urea-N versus SOM-N) under increasing soil

91 moisture regimes over a simulated fall season that included a urea addition followed by a strong

92 freeze-thaw cycle in soils that had experienced contrasting histories of manure management.

93 More specifically, this study focused on the dynamics of the $\mathrm{N}_{2} \mathrm{O}$ priming effects caused by fall-

94 added urea shortly after a sudden thawing. The following hypotheses were tested: i) compared

95 with soils without urea addition (control baseline), adding urea would trigger a positive priming

96 effect of $\mathrm{N}_{2} \mathrm{O}$ emissions derived from SOM-N; ii) larger priming of $\mathrm{N}_{2} \mathrm{O}$ production from SOM-

$97 \mathrm{~N}$ would occur in soils that had previously received recurrent manure applications; iii) increasing

98 soil moisture would amplify SOM-derived $\mathrm{N}_{2} \mathrm{O}$ production. 


\section{Materials and Methods}

\subsection{Soil collection}

101 Soils (0-15 cm depth) were collected from experimental plots receiving spring manure (SW) and

102 without a history of liquid manure injections (field control, CT). The soil was collected in

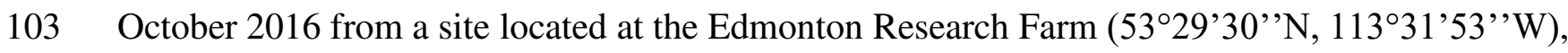

104 Alberta, Canada. The experimental site and field management have been described in Lin et al.

105 (2017). The physical and chemical properties of the soils are shown in Table 1. Field moist soils

106 were mixed and passed through an 8-mm sieve to homogenize and remove any large fragments

107 and plant residue. After mixing, subsamples were oven-dried $\left(105^{\circ} \mathrm{C}\right)$ for 24 hours to measure

108 the water content. Soils were stored at $2{ }^{\circ} \mathrm{C}$ until establishing the experiment.

109

\subsection{Experimental setup}

110 The experiment consisted of four sequential phases: i) an initial pre-conditioning phase, ii) a fall

111 phase including urea addition, iii) a freezing phase, and iv) thawing phase.

112 The experiment was established in 5.5-L plastic pots $21 \mathrm{~cm}$ in height and $19.8 \mathrm{~cm}$ in inner

113 diameter at the top of the container. In each pot, $5.5 \mathrm{~kg}$ of soil (as oven-dry equivalent) were

114 packed in increments up to $5.0 \mathrm{~L}(18.4 \mathrm{~cm}$ height $)$ to a bulk density of $1.1 \mathrm{~g} \mathrm{~cm}^{-3}$.

\section{$115 \quad 2.2 .1 \quad$ Pre-conditioning phase}

116 To restore and resemble the soil condition as found in cropped fields, we conducted an

117 initializing phase by growing wheat in all the pots in a greenhouse for 3 months. The air 
118 temperature in the greenhouse averaged $23{ }^{\circ} \mathrm{C}$ (ranging from 12 to $36{ }^{\circ} \mathrm{C}$ ). Twelve wheat seeds

119 (AC Muchmore, Canadian Western Red Spring cultivar) (FP Genetics, Regina, SK, Canada)

120 were planted to $4 \mathrm{~cm}$ soil depth in each pot in a circle about $1.5 \mathrm{~cm}$ from the pot edge. After

121 germination, the number of wheat plants was reduced to eight per pot. Soil moisture was kept at

$12257 \%$ water-filled pore space (WFPS) by weighting the pots and adding water every two days.

123 Once wheat reached tillering stage, all pots began receiving a $0.5 \mathrm{~g} \mathrm{~L}^{-1}$ of dissolved fertilizer

124 weekly (i.e., $20 \% \mathrm{~N}, 8 \% \mathrm{P}_{2} \mathrm{O}_{5}, 20 \% \mathrm{~K}_{2} \mathrm{O}, 0.5 \% \mathrm{Mg}, 0.02 \% \mathrm{~B}, 0.05 \% \mathrm{Cu}, 0.4 \% \mathrm{Fe}, 0.05 \% \mathrm{Mn}$,

$1250.005 \% \mathrm{Mo}, 0.05 \% \mathrm{Zn}$ and $2.8 \%$ ethylene diamine tetra-acetate as chelating agent). Throughout

126 the wheat growth period, each pot received an equivalent of $50.85 \mathrm{~kg} \mathrm{~N} \mathrm{ha}^{-1}$ according to typical

127 fertilizer recommendations (McKenzie et al. 2013). The aboveground plant biomass (>5 cm

128 height) was harvested and removed 3 months after seeding. To represent the crop residue, $5 \mathrm{~g}$ dry

129 matter of straw biomass was added to the soil surface of each pot. Two pots from each soil were

130 randomly selected for destructive soil sampling with the aim of measuring ammonium and

131 nitrate concentrations as well as ${ }^{15} \mathrm{~N}$ isotopic composition in natural abundance. Six soil cores

132 were taken from each of the two selected pots with an auger $(3.5 \mathrm{~cm}$ diameter and $18.4 \mathrm{~cm}$

133 depth). The other pots were sealed with caps and stored at $2{ }^{\circ} \mathrm{C}$ until the beginning of the next

134 experimental phase.

\section{$135 \quad$ 2.2.2 Treatment application and simulated fall phase}

136 Prior to applying the moisture and urea treatments, all pots were removed from $2{ }^{\circ} \mathrm{C}$ to room

137 temperature to facilitate air drying until reaching the target WFPS (e.g., 45\%). For each of the 
138 two soil managements (i.e., $\mathrm{CT}$ and $\mathrm{SW}$ ), three moisture regimes and two $\mathrm{N}$ additions were 139 applied as experimental treatments. The three soil moisture regimes were Low (i.e., WFPS of $14045 \%$ over the fall, reaching $70 \%$ during freezing, and falling to $55 \%$ by the end of the thawing 141 phase), Medium (i.e., 55-80-65\% WFPS) and High (65-90-75\% WFPS). The N addition 142 treatments were urea $\left(5\right.$ atom $\left.\%{ }^{15} \mathrm{~N}\right)$ (Sigma-Aldrich, St. Louis, MO, US) and control (without 143 urea addition). The experimental design was a factorial with three replicates. In sum, the three 144 experimental factors were: history of field manure injection (i.e., CT and SW), three moisture 145 regimes (Low, Medium and High), and $\mathrm{N}$ addition (urea and unamended control). A total of 36 146 experimental pots were used for flux measurement during the experiment.

147 The moisture and $\mathrm{N}$ addition treatments were established on Day 0 of the fall phase which lasted 148 for 27 days. The $\mathrm{N}$ addition consisted of $0.29 \mathrm{~g}$ of powder consistency 5 atom $\%{ }^{15} \mathrm{~N}$-urea per pot 149 placed at $5 \mathrm{~cm}$ depth to represent fertilizer banding. This rate was equivalent to $85 \mathrm{~kg} \mathrm{~N} \mathrm{ha}^{-1}$, 150 which simulates a common fall fertilization for a canola crop in the subsequent growing season. 151 After applying the $\mathrm{N}$ treatment, room-temperature deionized (DI) water was added to achieve fall 152 moisture levels of 45 (Low), 55 (Medium) and 65\% (High) WFPS. As necessary, the WFPS was 153 maintained by weighting the pots and adding DI water every day throughout the fall phase. All 154 pots and glass flasks with DI water were kept at $2^{\circ} \mathrm{C}$. Cardboard was placed $3-5 \mathrm{~cm}$ above the 155 top of the pots to prevent rapid evaporation while still allowing air circulation. 


\subsubsection{Simulated freezing phase}

157 On Day 28 after the beginning of the experiment, a freezing phase was started by moving all pots

158 from a temperature of 2 to $-18^{\circ} \mathrm{C}$. This freezing phase lasted for 27 days (i.e., Days 28 to 55

159 following the urea addition) which assured that the soil columns became completely frozen.

160 Additionally, to simulate multiple water inputs that accumulate over a typical winter in Central

161 Alberta (snow and ice precipitation), DI water (at $2^{\circ} \mathrm{C}$ ) was added during the freezing phase in

162 three successive increments. These water additions were done incrementally in amounts

163 equivalent to 8.3, 8.3 and 8.4\% WFPS on Days 31, 37 and 45, respectively. Upon melting, this

164 water input was calculated to increase the water content in the soil by a total of $25 \%$ WFPS,

165 which is a typical increase from fall to early spring. For the Low moisture regime, this meant a

166 change from 45 to $70 \%$ WFPS; for Medium moisture, from 55 to 80\%; for High moisture, from

16765 to $90 \%$. In line with typical winter conditions, most of the water added over the frozen

168 mesocosms solidified on the top of the soil surface and it remained frozen until the beginning of

169 the succeeding thawing phase when it melted and infiltrated into the soil column.

\section{$170 \quad$ 2.2.4 Simulated thawing}

171 On Day 56 after urea addition, all pots were moved from $-18{ }^{\circ} \mathrm{C}$ to room temperature conditions

172 to simulate a strong thawing. The room temperature averaged $23{ }^{\circ} \mathrm{C}$, ranging from 20.4 to 25.9

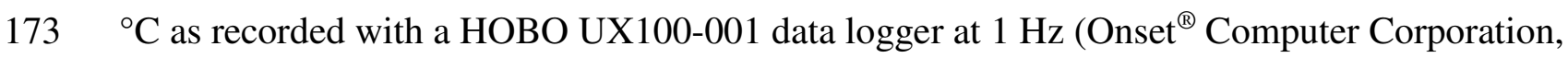

174 Bourne, MA, USA). After the rapid soil thawing on Day 56, soil moisture content was allowed to

175 gradually decrease by $0.5 \%$ WFPS daily. The total moisture decrease was $15 \%$ WFPS evenly 
176 distributed over 30 days (from Day 56 to 86 after the urea addition). Soil moisture content was

177 monitored and adjusted daily by weighting the pots and adding room temperature DI water as

178 necessary. On the last day of the experiment (Day 86), three soil cores were taken from each pot

179 with an auger $(3.5 \mathrm{~cm}$ diameter and $18.4 \mathrm{~cm}$ depth). These composite soil samples enabled us to

180 determine ammonium and nitrate concentrations as well as ${ }^{15} \mathrm{~N}$ isotopic composition.

\subsection{Measurements of $\mathrm{N}_{2} \mathrm{O}$ fluxes and isotopic composition}

182 The mixing ratios of ${ }^{14} \mathrm{~N}-{ }^{14} \mathrm{~N}-{ }^{16} \mathrm{O},{ }^{14} \mathrm{~N}-{ }^{15} \mathrm{~N}-{ }^{16} \mathrm{O}(\alpha)$ and ${ }^{15} \mathrm{~N}-{ }^{14} \mathrm{~N}-{ }^{16} \mathrm{O}(\beta)$ (Ostrom et al. 2021) were

183 quantified in a continuous mode via direct absorption spectroscopy at wavenumber of $2188 \mathrm{~cm}^{-1}$.

184 Briefly, the analyzer was an Aerodyne (Aerodyne Research, Inc., Billerica, MA, USA) with a

185 thermoelectrically-cooled, mid-infrared quantum cascade laser, equipped with 200-m path length

186 analytical cell (2 L volume at 30 Torr vacuum), and Nafion tubing (Perma Pure, Lakewood, New

187 Jersey, USA). Temperature $\left(20^{\circ} \mathrm{C}\right)$ and sample flow rate $\left(1.5\right.$ standard $\left.\mathrm{L} \min ^{-1}\right)$ were kept

188 constant in the instrumentation. TDLWintel software provided system control as well as data

189 acquisition and recording at $1 \mathrm{~Hz}$ resolution (Daly and Hernandez-Ramirez 2020).

190 Aerodyne analyzer was coupled with a flow-through, recirculation, non-steady-state chamber. A

191 custom-made cylindrical polyvinyl chloride chamber system consisted of a chamber base and a

192 chamber top. The cross-sectional area of the chamber was $184 \mathrm{~cm}^{2}(15.3 \mathrm{~cm}$ diameter). The

193 chamber base was installed $3 \mathrm{~cm}$ inside the soil, leaving $7 \mathrm{~cm}$ above the soil surface. These

194 chamber bases were installed at the center of each pot at the beginning of the fall phase. The

195 chamber top (5 $\mathrm{cm}$ in height) was equipped with two tubing connection ports for gas 
196 recirculation (one for inlet and another one for outlet), a stainless capillary tubing (3/16" in inner

197 diameter, $10 \mathrm{~cm}$ in length) on the wall for the purpose of pressure equilibration, and rubber seals

198 fitted to the chamber top to ensure headspace closure. The total chamber headspace was 2.2 L.

199 The chamber enclosure and sample recirculation with the Aerodyne lapsed for 3 minutes.

200 During every flux measurement, air temperature and pressure were recorded by a HOBO

201 UX100-001 data logger and a Testo 511 barometer (Testo Inc., Lenzkirch, Germany),

202 respectively.

\subsection{Measurements of $\mathrm{CO}_{2}$ fluxes}

204 During the fall and freezing phases, $\mathrm{CO}_{2}$ fluxes from the same soil pots were determined by a 205 simple system, which included a Picarro G2508 cavity ring-down spectroscope (CRDS) with a

$206105 \mathrm{~mL}$ analytical cell at a constant 140 Torr pressure and at a temperature of $45^{\circ} \mathrm{C}$ (Picarro, 207 Santa Clara, CA, USA), a low-leak diaphragm A0702 pump (Picarro, Santa Clara, CA, USA)

208 and the custom-made chamber described above. Similar to the $\mathrm{N}_{2} \mathrm{O}$ measurements with the

209 Aerodyne, a vacuum pump enabled the re-circulation of gas sample flow through the chamber

210 headspace at a rate of 240 standard $\mathrm{mL} \mathrm{min}^{-1}$ during an enclosure time of $3 \mathrm{~min}$.

211 After soil thawing (following Day 56 after the urea addition), $\mathrm{CO}_{2}$ fluxes were measured

212 with an automated chamber system, which included the CRDS described above, and an eosMX

213 multiplexer connected to 12 eosAC automated chambers (Eosense Inc., Dartmouth, NS, Canada)

214 (Roman-Perez and Hernandez-Ramirez 2021). The total headspace of the automated chamber

215 system was 2.8 L. Each flux measurement lapsed 10 min. 
217 The daily fluxes of $\mathrm{N}_{2} \mathrm{O}$ and $\mathrm{CO}_{2}$ were calculated as follows:

$$
F=\left(\frac{d C}{d t}\right) \times\left(\frac{V}{S}\right) \times\left(\frac{P}{R \times T}\right) \times M \times k
$$

218 where $\mathrm{F}$ is the gaseous flux $\left(\mu \mathrm{g} \mathrm{kg}^{-1} \mathrm{~d}^{-1}\right), \mathrm{dC} / \mathrm{dt}$ is the slope of a simple linear regression or as the

219 first derivative of a quadratic regression at $t_{0}\left(\mu \mathrm{L} \mathrm{L}^{-1} \mathrm{~s}^{-1}\right), \mathrm{V}$ is the headspace volume of the gas

220 chamber $(\mathrm{L}) ; \mathrm{S}$ is the dry soil weight $(\mathrm{kg}), \mathrm{P}$ is the pressure in the chamber headspace during

221 measurement (atm), $\mathrm{R}$ is the gas constant $\left(\mathrm{atm} \mu \mathrm{L} \mathrm{K}^{-1} \mu \mathrm{mol}^{-1}\right), \mathrm{T}$ is the temperature at chamber

222 headspace during measurement $(\mathrm{K}), \mathrm{M}$ is the molar mass of $\mathrm{N}$ within $\mathrm{N}_{2} \mathrm{O}\left(28 \mathrm{~g} \mathrm{~mol}^{-1}\right)$, or C

223 within $\mathrm{CO}_{2}\left(12 \mathrm{~g} \mathrm{~mol}^{-1}\right)$, and $\mathrm{k}$ is a conversion factor for the flux unit (from $\mu \mathrm{g} \mathrm{kg}^{-1} \mathrm{~s}^{-1}$ to $\mu \mathrm{g} \mathrm{kg}^{-1}$ $\left.224 \mathrm{~d}^{-1}\right)$.

\subsection{Calculations of $\mathrm{N}_{2} \mathrm{O}$ derived nitrification and denitrification}

226 With the aim of examining the contributions of nitrification and bacterial denitrification

227 processes to the total $\mathrm{N}_{2} \mathrm{O}$ production, the $\mathrm{N}_{2} \mathrm{O}$ measurements conducted 1 day after thawing

228 were used to estimate the site preference (SP) under natural abundance. This is because the large

$229 \mathrm{~N}_{2} \mathrm{O}$ production on this day improved the accuracy of isotopic ratio measurements (Waechter et

230 al. 2008).

231 Calculations for ${ }^{15 \alpha} \mathrm{R},{ }^{15 \beta} \mathrm{R}, \delta^{15 \alpha} \mathrm{N}_{2} \mathrm{O}, \delta^{15 \beta} \mathrm{N}_{2} \mathrm{O}$, and $\delta^{15 \text { bulk }} \mathrm{N}_{2} \mathrm{O}$ were as follows: 


$$
\begin{gathered}
{ }^{15 i} R=\frac{{ }^{15 i} N}{{ }^{14} N}(i=\alpha \text { or } \beta) \\
\delta^{15 i} N_{2} O=\left(\frac{{ }^{15 i} R_{\text {sample }}}{{ }^{15} R_{\text {std }}}-1\right) \times 1000(i=\alpha \text { or } \beta) \\
\delta^{15 b u l k} N_{2} O=\frac{\delta^{15 \alpha} N+\delta^{15 \beta} N}{2}
\end{gathered}
$$

232 where ${ }^{15 \alpha} \mathrm{N},{ }^{15 \beta} \mathrm{N}$ and ${ }^{14} \mathrm{~N}$ are the mixing ratios of ${ }^{15 \alpha} \mathrm{N}-\mathrm{N}_{2} \mathrm{O},{ }^{15 \beta} \mathrm{N}-\mathrm{N}_{2} \mathrm{O}$ and ${ }^{14} \mathrm{~N}-\mathrm{N}_{2} \mathrm{O}$ in the sample

233 as measured with Aerodyne, respectively; ${ }^{15 \alpha} \mathrm{R}$ is the isotopic ratio of ${ }^{15 \alpha} \mathrm{N}$ to ${ }^{14} \mathrm{~N} ;{ }^{15 \beta} \mathrm{R}$ is the ratio

234 of ${ }^{15 \beta} \mathrm{N}$ to ${ }^{14} \mathrm{~N} ;{ }^{15} \mathrm{R}_{\text {std }}$ is the isotopic ratio in the atmospheric dinitrogen $\left(\mathrm{N}_{2}\right)\left({ }^{15} \mathrm{R}_{\text {std }}=0.003676\right)$.

235 The $\delta^{15 \alpha} \mathrm{N}_{2} \mathrm{O}$ and $\delta^{15 \beta} \mathrm{N}_{2} \mathrm{O}$ emitted from each experimental pot during chamber enclosure was

236 obtained from the intercept of Keeling plots (i.e., from a linear regression of $\delta^{15 \alpha} \mathrm{N}_{2} \mathrm{O}, \delta^{15 \beta} \mathrm{N}_{2} \mathrm{O}$,

237 or atom $\%{ }^{15} \mathrm{~N}_{2} \mathrm{O}$ as y-axis vs. $1 /$ total $\mathrm{N}_{2} \mathrm{O}$ as $\mathrm{x}$-axis including 180 data points for each chamber

238 measurement of each replicated soil pot separately) (Harris et al. 2017, Thilakarathna and

239 Hernandez-Ramirez 2021).

240 The intramolecular ${ }^{15} \mathrm{~N}-\mathrm{N}_{2} \mathrm{O}$ SP was calculated as follows:

$$
S P=\delta^{15 \alpha} N_{2} O-\delta^{15 \beta} N_{2} O
$$

241 The isotopic fractionation effect of the transformation from $\mathrm{N}_{2} \mathrm{O}$ to $\mathrm{N}_{2}$ was accounted for based

242 on relationships between $\delta^{15} \mathrm{~N}_{2} \mathrm{O}$ and SP (Yamamoto et al. 2017, Congreves et al. 2019). The 
243 resultant changes in SP magnitude were minor (Daly and Hernandez-Ramirez 2020), extending

244 from negligible to $-2.5 \%$ in only $6 \%$ of the individual measurements.

245 The contributions of nitrification and bacterial denitrification to $\mathrm{N}_{2} \mathrm{O}$ production were calculated 246 as follows:

$$
\begin{gathered}
F_{n i}(\%)=\frac{S P}{33} \times 100 \\
F_{\text {deni }}(\%)=\frac{33-S P}{33} \times 100
\end{gathered}
$$

247 where $\mathrm{F}_{\mathrm{ni}}$ and $\mathrm{F}_{\mathrm{deni}}$ are the proportional contributions of nitrification and denitrification,

248 respectively. This assumes that the SPs of the nitrification and denitrification sources are 0 and

$24933 \%$, respectively (Sutka et al. 2006).

\subsection{Calculation of the $\mathrm{N}_{2} \mathrm{O}$ derived from $\mathrm{SOM}-\mathrm{N}$ and the priming effects}

251 As our study used urea labelled with ${ }^{15} \mathrm{~N}$, a mass balance based on isotopic composition of 252 the emitted $\mathrm{N}_{2} \mathrm{O}$ (atom\%) was conducted to separate the contributions of two $\mathrm{N}$ pools (i.e., added 253 urea-N vs. existing SOM-N sources) to the overall $\mathrm{N}_{2} \mathrm{O}$ flux using the entire dataset over the 254 thawing phase. Atom $\%{ }^{15} \mathrm{~N}_{2} \mathrm{O}$ is the isotopic percentage of ${ }^{15} \mathrm{~N}$ in $\mathrm{N}_{2} \mathrm{O}$ as follows:

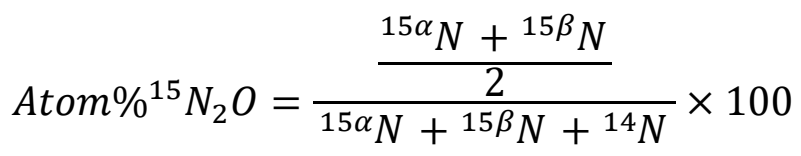


256 experimental soil pot during each chamber enclosure was obtained from the Keeling plot

257 intercepts.

259 calculated as follows:

$$
\begin{gathered}
F N_{2} O_{15 N-\text { urea }}(\%)=\frac{\text { Atom } \%{ }^{15} \mathrm{~N}_{2} \mathrm{O}_{15 N \text {-urea }}-\text { Atom } \%{ }^{15} \mathrm{~N}_{2} \mathrm{O}_{\text {control }}}{5 \%-\text { Atom } \%^{15} \mathrm{~N}_{2} \mathrm{O}_{\text {control }}} \\
\mathrm{FN}_{2} \mathrm{O}_{\text {SOM }}(\%)=\frac{5 \%-\text { Atom } \%{ }^{15} \mathrm{~N}_{2} \mathrm{O}_{15 N-\text { urea }}}{5 \%-\text { Atom } \%{ }^{15} \mathrm{~N}_{2} \mathrm{O}_{\text {control }}} \\
\mathrm{N}_{2} \mathrm{O}_{\text {SOM }}=F N_{2} \mathrm{O}_{\text {SOM }} \times N_{2} O \text { flux from urea ammended soil }
\end{gathered}
$$

260 where $\mathrm{FN}_{2} \mathrm{O}_{15 \mathrm{~N} \text {-urea }}$ and $\mathrm{FN}_{2} \mathrm{O}_{\text {SOM }}$ are the fractions of $\mathrm{N}_{2} \mathrm{O}$ production derived from added ${ }^{15} \mathrm{~N}$ 261 urea and from existing SOM-N, respectively; Atom $\%{ }^{15} \mathrm{~N}_{2} \mathrm{O}_{15 \mathrm{~N}-\text { urea }}$ and Atom $\%{ }^{15} \mathrm{~N}_{2} \mathrm{O}_{\text {control }}$ are the 262 isotopic percentages of ${ }^{15} \mathrm{~N}$ in $\mathrm{N}_{2} \mathrm{O}$ emitted from the experimental pots with and without added 263 urea, respectively; $\mathrm{N}_{2} \mathrm{O}_{\text {control }}$ is the $\mathrm{N}_{2} \mathrm{O}$ flux from the control soils (without urea).

The priming effect of daily $\mathrm{N}_{2} \mathrm{O}$ fluxes was calculated as follows:

$$
\mathrm{N}_{2} \mathrm{O} \text { priming effect }=\mathrm{N}_{2} \mathrm{O}_{\text {SOM }}-\mathrm{N}_{2} \mathrm{O}_{\text {control }}
$$

265 In the Eq. [12], $\mathrm{N}_{2} \mathrm{O}$ priming effect $>0$ corresponds to a positive priming effect caused by 266 added urea, whereas $<0$ indicates a negative priming effect. More specifically, daily negative 
267 priming was identified when the mean daily SOM-derived $\mathrm{N}_{2} \mathrm{O}$ flux from a urea-amended soil

268 was one standard error below the zero baseline (which was defined as the corresponding control

269 without urea addition). Results of $\mathrm{N}_{2} \mathrm{O}$ priming were expressed as magnitude and also in relative

270 basis as a percentage of the total flux for each soil pot receiving urea.

271 Cumulative fluxes of total $\mathrm{N}_{2} \mathrm{O}$ and $\mathrm{CO}_{2}$ as well as urea-derived $\mathrm{N}_{2} \mathrm{O}$, SOM-derived $\mathrm{N}_{2} \mathrm{O}$

272 and primed $\mathrm{N}_{2} \mathrm{O}$ after thawing were calculated by linear interpolations of the consecutive daily

273 flux measurements.

\subsection{Measurements of soil properties}

275 Soils were air dried and passed through a $2 \mathrm{~mm}$ mesh prior to analyses. Soil extractable $\mathrm{NH}_{4}^{+}$

276 and $\mathrm{NO}_{3}{ }^{-}$in the filtrate $(2 \mathrm{M} \mathrm{KCl})$ were determined by using a SmartChem 200 Discrete Wet

277 Chemistry Analyzer (Westco Scientific Instruments, Inc., Brookfield, CT, US) (McKeague 1978,

278 Carter and Gregorich 2007). The soil organic C and total N were determined by a dry

279 combustion method in a Costech Model EA 4010 Elemental analyzer (Costech International

280 Strumatzione, Florence, Italy). The clay, silt and sand percentages were determined by the rate of

281 settling in a solution with a hydrometer (McKeague 1978, Carter and Gregorich 2007). Soil pH

282 was determined in a mixture with a soil-to-water ratio of 1:2 (McKeague 1978, Carter and

283 Gregorich 2007).

284 With the aim of measuring ${ }^{15} \mathrm{~N}$ isotopic composition in the soil at natural abundance (without

285 addition of labelled urea), soil samples were oven-dried at $60{ }^{\circ} \mathrm{C}$ and ball-ground to a fine

286 consistency to ensure homogeneity for isotope analysis. The soil $\delta^{15} \mathrm{~N}$ was determined by using a 
287 Flash 2000 Elemental Analyzer (Thermo Fisher Scientific, Delft, Netherlands) to dry combust 288 the soil sample converting all $\mathrm{N}$ to $\mathrm{N}_{2}$. This analyzer was interfaced online to a Finnigan Delta V 289 Plus isotopic ratio mass spectrometer (Thermo Electron, Bremen, Germany) to detect the ${ }^{15} \mathrm{~N}$ 290 isotope composition.

291 Based on the ${ }^{15} \mathrm{~N}$ isotopic compositions of soil $\mathrm{N}$ and $\mathrm{N}_{2} \mathrm{O}$ emitted from control soils, isotope 292 discrimination $(\varepsilon)$ was calculated as follows:

$$
\varepsilon(\%)=\left(\frac{{ }^{15} R_{N 2 O}}{15 R_{\text {soilN }}}-1\right) \times 1000
$$

293 where ${ }^{15} \mathrm{R}_{\mathrm{N} 2 \mathrm{O}}$ is the isotopic ratio of $\mathrm{N}_{2} \mathrm{O}$ emitted on Day 57 (1 day after thawing) and ${ }^{15} \mathrm{R}_{\text {soilN }}$ is

294 the isotopic ratio of soil N. A positive $\varepsilon$ implies the enrichment of ${ }^{15} \mathrm{~N}$ during the processes of 295 transforming soil $\mathrm{N}$ to $\mathrm{N}_{2} \mathrm{O}$ emissions; a negative $\varepsilon$ implies a depletion of ${ }^{15} \mathrm{~N}$ during this 296 conversion from soil $\mathrm{N}$ to emitted $\mathrm{N}_{2} \mathrm{O}$. This $\varepsilon$ estimation was based on the premise that the 297 transformation from the SOM-N pools into the emitted $\mathrm{N}_{2} \mathrm{O}$ pool was unidirectional.

\subsection{Statistical analyses}

299 Statistical analyses were performed in R 3.1.3 (R Core Team 2014) at alpha critical value of $300 \quad 0.05$. The data were transformed to meet the assumptions of normality and homoscedasticity as 301 necessary. The effects of manure history (CT vs. SW soils), N (urea vs. control) and soil water 302 content (Low, Medium vs. High) treatments on soil $\mathrm{NH}_{4}{ }^{+}, \mathrm{NO}_{3}{ }^{-}$, cumulative $\mathrm{N}_{2} \mathrm{O}, \mathrm{SOM}$-derived $303 \mathrm{~N}_{2} \mathrm{O}$ and cumulative $\mathrm{CO}_{2}$ were examined by three-way analysis of variance (ANOVA) for a 304 fixed-effect model with interaction analysis. We run two-way analysis ANOVA for a fixed- 
305 effect model to determine the effects of manure history and water content on primed $\mathrm{N}_{2} \mathrm{O}$ and

306 urea-derived $\mathrm{N}_{2} \mathrm{O}$ as well as the differences in the contributions of nitrification and

307 denitrification to the $\mathrm{N}_{2} \mathrm{O}$ emitted 1 day after thawing. Tukey's Honest Significant Difference

308 (HSD) test was used to compare the difference further in cases where the treatment effects

309 described above were significant.

\section{3. Results}

\subsection{Daily and cumulative fluxes of total $\mathrm{N}_{2} \mathrm{O}$ production}

312 Throughout the fall and freezing phases, $\mathrm{N}_{2} \mathrm{O}$ production was relatively low (Fig. 1). Shortly

313 after the urea and water treatments were established at the beginning of the fall phase, the

314 average daily $\mathrm{N}_{2} \mathrm{O}$ flux rose up to $0.75 \pm 0.20 \mu \mathrm{g} \mathrm{N}_{2} \mathrm{O}-\mathrm{N} \mathrm{kg}^{-1} \mathrm{~d}^{-1}$ on Day 3, then dropped to 0.17

$315 \pm 0.01 \mu \mathrm{g} \mathrm{N}_{2} \mathrm{O}-\mathrm{N} \mathrm{kg}^{-1} \mathrm{~d}^{-1}$ by Day 9 , followed by a gradual increase up to $1.23 \pm 0.40 \mu \mathrm{g} \mathrm{N} \mathrm{N}_{2} \mathrm{O}-\mathrm{N}$

$316 \mathrm{~kg}^{-1} \mathrm{~d}^{-1}$ on the last day of the fall phase (Fig. 1). During the freezing phase, the average daily

$317 \mathrm{~N}_{2} \mathrm{O}$ fluxes were consistently low at $0.22 \pm 0.02 \mu \mathrm{g} \mathrm{N}_{2} \mathrm{O}-\mathrm{N} \mathrm{kg}^{-1}$ soil d ${ }^{-1}$ (Fig. 1).

318 Robust $\mathrm{N}_{2} \mathrm{O}$ fluxes occurred after soil thawing (Fig. 1). Overall, daily $\mathrm{N}_{2} \mathrm{O}$ fluxes reached a peak

319 of $71.44 \pm 7.08 \mu \mathrm{g} \mathrm{N}_{2} \mathrm{O}-\mathrm{N} \mathrm{kg}^{-1} \mathrm{~d}^{-1}$ one day after thawing (on Day 57 of the experiment). More

320 specifically, soils under the Low and Medium moisture regimes peaked on Day 57, whereas soils

321 under High moisture showed an even larger peak on Day 58. After that, fluxes quickly declined

322 to $17.66 \pm 3.90 \mu \mathrm{g} \mathrm{N}_{2} \mathrm{O}-\mathrm{N} \mathrm{kg}^{-1} \mathrm{~d}^{-1} 5$ days after thawing (Day 61 of the experiment) (Fig. 1). 
323 Subsequently, daily $\mathrm{N}_{2} \mathrm{O}$ fluxes continued to decrease gradually. The fluxes on the last day of the

324 experiment (Day 86) averaged $0.76 \pm 0.18 \mu \mathrm{g} \mathrm{N}_{2} \mathrm{O}-\mathrm{N} \mathrm{kg}^{-1} \mathrm{~d}^{-1}$ (Fig. 1).

325 Following thawing, cumulative $\mathrm{N}_{2} \mathrm{O}$ emissions were significantly impacted by the history of

326 manure applications $(\mathrm{SW}>\mathrm{CT})$, soil water regime (High > Medium $>$ Low) and urea addition

327 (urea-N > control) (Table 2, Fig. 2a).

\section{2 $\mathrm{N}_{2} \mathrm{O}$ production derived specifically from $\mathrm{SOM}-\mathrm{N}$ and priming effects}

329 In parallel with the results of total $\mathrm{N}_{2} \mathrm{O}$ emissions, the main effects of urea addition, moisture

330 content, and history of manure applications showed separate, significant impact on the

331 cumulative $\mathrm{N}_{2} \mathrm{O}$ production derived from SOM during the period after thawing (Table 2, Fig.

332 2a). It is noted that the interactions amongst these three experimental factors were not significant.

333 Irrespective of soil moisture and manure history effects, soils subjected to fall-banded urea were

334 consistently higher in cumulative SOM-derived $\mathrm{N}_{2} \mathrm{O}$ emissions after thawing than the control

335 soils by a difference of $24 \%$ (305 vs. $245 \mu \mathrm{g} \mathrm{N}_{2} \mathrm{O}-\mathrm{N} \mathrm{kg}^{-1}$ soil, $P=0.022$; Fig. $2 \mathrm{a}$ ); this

336 substantiates a positive priming effect of SOM that took place following the rapid, wet thawing

337 of the soils. Furthermore, increasing moisture also significantly increased SOM-derived $\mathrm{N}_{2} \mathrm{O}$

338 emissions (Low: $197 \mu \mathrm{g} \mathrm{N}_{2} \mathrm{O}-\mathrm{N} \mathrm{kg}^{-1}$ soil, Medium: 292, vs. High: 473, $P<0.001$ ). Likewise,

339 having a history of manure application ( $\mathrm{SW}$ soil) showed to raise the SOM-derived $\mathrm{N}_{2} \mathrm{O}$

340 emissions by $39 \%$ above those of the CT soil (374 vs. $268 \mu \mathrm{g} \mathrm{N} \mathrm{N}_{2} \mathrm{O}-\mathrm{N} \mathrm{kg}^{-1}$ soil, $P=0.002$ ).

341 Specifically, there was a tendency for the SW soil to have a numerically higher positive priming 
342 effect compared with the CT soil in both magnitude (Fig. 2 b) and relative (+17 vs. $+6 \%$ Fig. 2 c)

343 basis.

344 Most of the daily $\mathrm{N}_{2} \mathrm{O}$ fluxes following soil thawing showed positive priming (Fig. 3). Soils

345 under Low moisture regime showed a peak of primed daily $\mathrm{N}_{2} \mathrm{O}$ fluxes 1 day after thawing (Fig.

346 3a). In the case of soils under Medium and High moisture regimes, the peak of positive priming

347 in daily $\mathrm{N}_{2} \mathrm{O}$ fluxes occurred 1 day later (i.e., 2 days after thawing) (Fig. $3 \mathrm{~b}$ and Fig. 3c). Across

348 the three moistures in the SW soil, the peak of daily positive priming was greater at the two

349 higher moisture contents $\left(29.44 \mu \mathrm{g} \mathrm{N}_{2} \mathrm{O}-\mathrm{N} \mathrm{kg}^{-1} \mathrm{~d}^{-1}\right.$ at Low vs. 62.95 at Medium and 52.82 at

350 High moisture content). Overall, peak primings were greater for SW than for CT soil under both

351 Medium and High soil moisture regimes (Fig. 3). In general, following these early peaks, primed

$352 \mathrm{~N}_{2} \mathrm{O}$ fluxes gradually dropped back to approximately the zero baseline.

353 Interestingly, about 2 weeks after soil thawing, negative priming of daily $\mathrm{N}_{2} \mathrm{O}$ fluxes was clearly

354 observed (i.e., SOM-derived $\mathrm{N}_{2} \mathrm{O} \ll<$ control $\mathrm{N}_{2} \mathrm{O}$ ). These episodes of evident negative primings

355 occurred only under High soil moisture for both SW and CT soils (Fig. 3c). The negative

356 priming effect began slightly earlier in the SW soil (Day 70 of the experiment) than in the CT

357 soil (Day 71) (Fig. 3c). The last day that registered negative priming effect in SW soil was Day

35886 of the experiment; in CT soil, it was Day 85. Towards the end of the experiment, the

359 magnitude of the priming effects returned to zero or became minor. Collectively, the results

360 indicate that higher moisture generated more dynamic priming activity. 
361 Contrary to the wide responses of cumulative and daily SOM-derived $\mathrm{N}_{2} \mathrm{O}$ fluxes to urea

362 addition, history of manure applications and soil moisture as aforementioned, the direct

363 contribution of the urea- $\mathrm{N}$ source to cumulative $\mathrm{N}_{2} \mathrm{O}$ fluxes (urea-derived $\mathrm{N}_{2} \mathrm{O}$ ) was consistent

364 across all assessed experimental factors and treatment combinations, with no significant effects

365 caused by manure history or soil moisture (Table 2, Fig. 2a).

\subsection{Contributions of denitrification to the peak of $\mathrm{N}_{2} \mathrm{O}$ fluxes}

367 The very large $\mathrm{N}_{2} \mathrm{O}$ fluxes that occurred 1 day after soil thawing provided the opportunity to

368 measure and allocate the $\mathrm{N}_{2} \mathrm{O}$ produced from nitrification and denitrification sources in all

369 unamended control soils (i.e., under natural ${ }^{15} \mathrm{~N}$ abundance conditions) and across the three

370 moisture contents (Fig. 4). The results for ${ }^{15} \mathrm{~N}-\mathrm{N}_{2} \mathrm{O}$ SP ranged from $1.0 \%$ in the CT soil under

371 High moisture to $5.7 \%$ in the SW soil under Medium moisture $(P>0.05)$ (Fig. 4c). This suggest

372 that denitrification dominated the vigorous $\mathrm{N}_{2} \mathrm{O}$ production, with $83 \%$ contribution in the case of

373 the SW soil under Medium moisture and up to nearly all the $\mathrm{N}_{2} \mathrm{O}$ produced in the case of the CT

374 soil under High moisture (97\%) (Fig. 4b). When averaging across the three moistures, the

375 relative contributions of denitrification to $\mathrm{N}_{2} \mathrm{O}$ production in the CT soil were marginal-

376 significantly larger than those in the SW soil ( $P=0.06$; Fig. $4 b)$.

\subsection{Isotopic depletion of ${ }^{15} \mathrm{~N}-\mathrm{N}_{2} \mathrm{O}$ relative to soil $\mathrm{N}$}

378 There was a consistently negative depletion of ${ }^{15} \mathrm{~N}(\varepsilon)$ during the transformation from the soil $\mathrm{N}$

379 pool to the emitted $\mathrm{N}_{2} \mathrm{O}$ pool across all soil management histories and water regimes (Table 3). 
381 There were no significant effects of experimental factors on the $\mathrm{NH}_{4}{ }^{+}$concentrations (Table 2).

382 There was a significant interaction of manure history and water content on soil $\mathrm{NO}_{3}{ }^{-}$

383 concentrations (Table 2, Fig. 5). Specifically, irrespective of urea addition, soil $\mathrm{NO}_{3}{ }^{-}$

384 concentration was significantly lower in the treatment combination of CT soil at Low moisture

385 than most of other treatments, with the only exception of the treatment combination of CT soil at

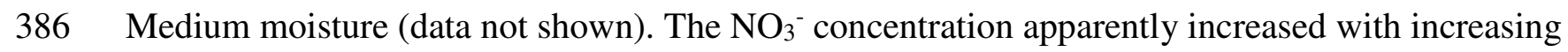

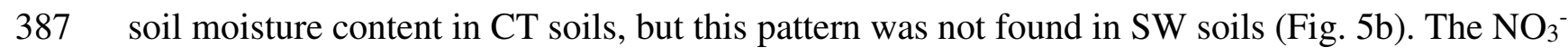

388 concentration was in general greater in the SW soil than the CT soil (Fig. 5b). As expected, soils

389 receiving added urea had greater increments in the $\mathrm{NO}_{3}{ }^{-}$concentration than the soil without urea

390 (i.e., $\mathrm{CT}+$ urea $>\mathrm{CT}$ control; $\mathrm{SW}+$ urea $>\mathrm{SW}$ control, Fig. 5b). These increased nitrate

391 concentrations indicate the occurrence of nitrification in these soils. Furthermore, both $\mathrm{NH}_{4}{ }^{+}$and

$392 \mathrm{NO}_{3}{ }^{-}$concentrations increased over time from the beginning to the end of the experiment,

393 including in the control soils; therefore, this indicates that active mineralization and

394 ammonification from SOM-N also took place over the experimental period.

\section{$395 \quad 3.6 \quad$ Soil $\mathrm{CO}_{2}$ fluxes}

396 Within most of the fall and freezing phases, $\mathrm{CO}_{2}$ fluxes were generally low and relatively stable 397 across all treatment combinations. Over the fall phase, $\mathrm{CO}_{2}$ fluxes averaged $1.29 \pm 0.13 \mu \mathrm{g} \mathrm{CO}_{2-}$ $398 \mathrm{C} \mathrm{kg}^{-1} \mathrm{~d}^{-1}$ (Fig. 1c). Afterwards, $\mathrm{CO}_{2}$ fluxes steadily decreased to $0.57 \pm 0.14 \mu \mathrm{g} \mathrm{CO}_{2}-\mathrm{C} \mathrm{kg}^{-1} \mathrm{~d}^{-1}$ 399 on Day 6 of the freezing phase, and then became negligible (Fig. 1c). 
400 Similar to $\mathrm{N}_{2} \mathrm{O}$ fluxes, most of the dynamics of $\mathrm{CO}_{2}$ fluxes took place shortly after soil thawing 401 (Fig. 1). Three days after thawing, the average $\mathrm{CO}_{2}$ flux across all treatments sharply peaked at $4028.65 \pm 0.29 \mu \mathrm{g} \mathrm{CO}_{2}-\mathrm{C} \mathrm{kg}^{-1} \mathrm{~d}^{-1}$. Thereafter, $\mathrm{CO}_{2}$ fluxes slowly decreased over time, reaching 1.94 $403 \pm 0.16 \mu \mathrm{g} \mathrm{CO}_{2}-\mathrm{C} \mathrm{kg}^{-1} \mathrm{~d}^{-1}$ on the last day of the experiment (Fig. 1c). It is noted that there was a 404 strong correlation between daily $\mathrm{CO}_{2}$ and $\mathrm{N}_{2} \mathrm{O}$ fluxes following thawing $(\mathrm{r}=0.968, P<0.001$;

405 Supplementary Fig. 1 and Fig. 1), with the exception of the first 3 days after thawing when the $406 \mathrm{~N}_{2} \mathrm{O}$ fluxes were decoupled and disproportionally larger than the measured $\mathrm{CO}_{2}$ fluxes.

407 Over the entire experiment and specifically in the period after thawing, the cumulative $\mathrm{CO}_{2}$ 408 emissions significantly increasing with higher soil moisture in the SW soil that had not received 409 fall-urea (data not shown; Table 2).

410 4. Discussion

\subsection{Added urea triggered primed $\mathrm{N}_{2} \mathrm{O}$ emissions derived from $\mathrm{SOM}-\mathrm{N}$}

412 Results suggest that fall-applied N fertilizer induces a net positive priming effect from SOM-N at

413 the onset of the subsequent spring thaw. This is consistent with earlier studies showing that fall

$414 \mathrm{~N}$ applications lead to large thaw-associated $\mathrm{N}_{2} \mathrm{O}$ emissions (Burton et al. 2008, Lin et al. 2017).

415 This is the first time in the literature that the direction and magnitude of potential priming effects 416 on augmented $\mathrm{N}_{2} \mathrm{O}$ emissions shortly after thawing has been quantified (Fig. 2, Fig. 3). These

417 results suggest that mineralization of SOM increases over a strong freeze-thawing cycle because 418 of the indirect influence of an earlier fall-banded urea, leading to large gaseous $\mathrm{N}$ losses at the 
onset of thawing. Shortly after thawing, the input of extra $\mathrm{N}$ substrates from added urea in

420 conjunction with heat and moisture activated microbial activity, collectively accelerating SOM-

421 N availability (Curtin et al. 2012, Curtin et al. 2014). Such additional mineralized SOM-N in the

422 soils amended with urea would become available for nitrifiers and denitrifiers, consequently

423 producing extra SOM-derived $\mathrm{N}_{2} \mathrm{O}$ fluxes consistently above the unamended baseline soils.

424 Recent studies have postulated a stoichemetry-based hypothesis with the aim to explain how an

425 addition of labile N (e.g., urea) could prime SOM mineralization (Chen et al. 2014, Roman-Perez

426 and Hernandez-Ramirez 2021). This hypothesis is centered on stoichemetric pre-requirements

427 for SOM decomposition where adding labile $\mathrm{N}$ to soils rich in SOM satisfies microbial requisites

428 for undertaking faster decomposition and mineralization of the existing SOM.

\subsection{Influence of manure history on $\mathrm{N}_{2} \mathrm{O}$ emissions derived from $\mathrm{SOM}-\mathrm{N}$}

430 In addition to the priming of SOM-N caused by labile $\mathrm{N}$ additions, soils can be predisposed to 431 exhibiting inherent priming because of the legacy effects from earlier management choices

432 (Ginting et al. 2003, Blagodatskaya et al. 2007, Thilakarathna and Hernandez-Ramirez 2021). It

433 is plausible that the manured soils (SW) in our study showed a more intense response of primed

$434 \quad \mathrm{~N}_{2} \mathrm{O}$ dynamics to the fall-applied urea because the previous field manure injections in this soil

435 had increased the easily decomposable SOM. It is noted that the SW soil showed a tendency for

436 higher organic C concentrations than CT (Table 1). Conversely, it is acknowledged that

437 increasing SOM concentrations have shown to lead to microbial immobilization of the available

438 N in certain studies (Hou et al. 2000, Zimmerman et al. 2011). Moreover, availability of labile

439 organic $\mathrm{C}$ could also reduce the $\mathrm{N}_{2} \mathrm{O}$ priming in urea-amended soils. This is explained by the 
440 increased conversion of $\mathrm{N}_{2} \mathrm{O}$ into $\mathrm{N}_{2}$ as driven by heterotrophic utilization of organic $\mathrm{C}$ that

441 enhances the last step of bacterial denitrification (Daly and Hernandez-Ramirez 2020). Future

442 research focusing on these drivers of $\mathrm{N}_{2} \mathrm{O}$ priming would help to deepen our understanding of $\mathrm{C}$

443 and $\mathrm{N}$ turnover in soils, particularly in agricultural systems that experience high, frequent

444 nutrient outputs and inputs such as croplands that receive heavy manure additions. We

445 hypothesize that in environments that are N-rich and even N-saturated, coupling availabilities of

$446 \mathrm{C}$ and $\mathrm{N}$ could reduce and even cancel the potential priming effects on $\mathrm{N}_{2} \mathrm{O}$ emissions derived

447 from SOM-N.

\subsection{Moisture regime altered the $\mathrm{N}_{2} \mathrm{O}$ produced from $\mathrm{SOM}-\mathrm{N}$}

449 In addition to the effects of contrasting manure history on $\mathrm{N}_{2} \mathrm{O}$ priming following thawing, soil

450 moisture clearly affected the dynamics of primed $\mathrm{N}_{2} \mathrm{O}$ fluxes as well. Although the overall

451 priming was positive across all experimental combinations, only soils under High moisture

452 experienced negative $\mathrm{N}_{2} \mathrm{O}$ priming of daily fluxes and also longer-lasting priming effects as

453 noted above (Fig. 3). The temporal shift of daily priming effects from positive to negative and

454 eventually back to zero priming at High moisture could be explained by the mechanism of

455 preferential substrate utilization. The hypothesis of preferential substrate utilization states that

456 when given a variety of nutrient supplies, microorganisms prefer easily available and highly

457 accessible substrates over recalcitrant substrates (Cheng 1999, Cheng and Kuzyakov 2005,

458 Blagodatskaya and Kuzyakov 2008). Within the context of our study, it could be postulated that

459 at the onset of thawing, soil microbes initially utilized the easily available substrates, and then

460 switched to consuming more complex substrates (e.g., wheat straw residues and roots) in 
461 conjunction with any available inorganic $\mathrm{N}$, and eventually started utilizing the recalcitrant

462 SOM. When the soil microbes switch to decomposing plant residues, they would need to uptake

463 inorganic $\mathrm{N}$ available from the soil solution because of the high $\mathrm{C}: \mathrm{N}$ ratios of wheat straw and

464 roots (Gan et al. 2011); this would induce a temporary net $\mathrm{N}$ immobilization, which may have

465 generated the temporal negative priming of $\mathrm{N}_{2} \mathrm{O}$ production observed in the urea-amended soils

466 under High moisture. It is noted that although all assessed soils could possibly experience this

467 phenomenon, this is particularly crucial in the soils that had received urea because there was

468 more inorganic $\mathrm{N}$ available to conduct this temporal immobilization. Additionally, this short-

469 term immobilization could even entail a pool substitution of urea-N in lieu of native inorganic $\mathrm{N}$.

470 These episodes of negative priming could have also become more evident under higher water

471 content because increasing moisture has been found to favor greater SOM-N mineralization and

472 nitrification (Stanford and Epstein 1974, Paul et al. 2003, Curtin et al. 2012, Curtin et al. 2014).

473 The higher $\mathrm{N}$ availability with increasing water content is partly shown by the tendency of

474 increased $\mathrm{NH}_{4}{ }^{+}$and $\mathrm{NO}_{3}{ }^{-}$concentrations with higher moisture in the $\mathrm{CT}$ soils at the end of the

475 experiment (Fig. 5). In other words, with the decrease in the availability of more easily-

476 decomposable substrates, soil microorganisms can progressively utilize recalcitrant SOM to

477 sustain their ongoing metabolism and growth, which subsequently causes additional $\mathrm{N}$

478 mineralization coupled with a gradually-diminishing negative priming of $\mathrm{N}_{2} \mathrm{O}$ production, and

479 this can finally shift the soil system to steadily approach neutral priming.

480 Provided that climate change predictions include higher precipitation over the fall and winter

481 seasons in the North American Plains (Easterling et al. 2017), our study demonstrates the 
482 potential for exacerbated $\mathrm{N}_{2} \mathrm{O}$ emissions in the early spring soon after a wet thawing, which was

483 primarily driven by increased $\mathrm{N}_{2} \mathrm{O}$ production from $\mathrm{SOM}$ in fertilized, near water-saturated soils

484 (Fig. 2a). This interpretation is consistent with previous studies that evaluated the driving effects

485 of increasing moisture on $\mathrm{N}_{2} \mathrm{O}$ peak emissions (Hou, A. et al. 2000, Lin and Hernandez-Ramirez

486 2020, Roman-Perez and Hernandez-Ramirez 2021). Increasing moisture and microbial activity

487 immediately after soil thawing can have led to the depletion of $\mathrm{O}_{2}$ concentrations in the soil

488 microsites, and hence mediating an increased $\mathrm{N}_{2} \mathrm{O}$ production from denitrification (Yanai et al.

489 2011).

\subsection{Main processes producing $\mathrm{N}_{2} \mathrm{O}$ shortly after soil thawing}

491 Irrespective of different soil manure history and moisture levels, the consistent negative isotope 492 discrimination $(\varepsilon)$ indicated ${ }^{15} \mathrm{~N}$ depletion during the transformation of the SOM-N to the major $493 \mathrm{~N}_{2} \mathrm{O}$ fluxes just emitted 1 day after thawing (Table 3). This further suggests that the SOM-N pool 494 was the dominant source for substantial $\mathrm{N}_{2} \mathrm{O}$ production in our study because several SOM-N 495 transformations in soils such as mineralization, nitrification and denitrification are known to 496 fractionate against the heavier isotope (i.e., ${ }^{15} \mathrm{~N}$ ), resulting in ${ }^{15} \mathrm{~N}$ depletion in the $\mathrm{N}_{2} \mathrm{O}$ product 497 compared to the remaining SOM-N substrate (Högberg 1997). However, it is acknowledged that 498 this specific data were available only one time over the experiment while the key processes 499 responsible for $\mathrm{N}_{2} \mathrm{O}$ production (nitrification vs. bacterial denitrification) can fluctuate within a 500 few hours or days. If we consider denitrification to be the main source of significant peak $\mathrm{N}_{2} \mathrm{O}$ 501 production following the simulation of a strong soil thawing (Fig. 3), abundant soil $\mathrm{NO}_{3}{ }^{-}$(and 502 including the intermediate nitrite) pool inexorably played a role as the primary $\mathrm{N}$ substrate 
503 contributing to the large $\mathrm{N}_{2} \mathrm{O}$ emissions instead of $\mathrm{NH}_{4}{ }^{+}$(and the intermediate hydroxylamine

504 substrate). On the other hand, nitrification could become a key source for $\mathrm{N}_{2} \mathrm{O}$ emissions in soils 505 under lower water contents or in years when spring thawing is mild (Davidson 1991, Ruser et al. 506 2006).

\section{5. Conclusions}

508 Adding urea asymmetrically increase the primed $\mathrm{N}_{2} \mathrm{O}$ emissions specifically derived from SOM-

509 N. Results indicated that annual croplands receiving fall-banded urea followed by a strong

510 freeze-thaw cycle can manifest accelerated SOM transformations that intensify $\mathrm{N}_{2} \mathrm{O}$ emissions in

511 the early spring. In addition to these priming effects triggered by the added urea, $\mathrm{N}_{2} \mathrm{O}$ production

512 from SOM was further amplified in soils that have had a recent history of manure applications or 513 experienced increasing moisture during spring thawing. 


\section{6. Acknowledgements}

516 The authors are very thankful for the technical and human support by Leanne Chai, Kurt Forsch,

517 Rebecca Keating, Alan Lee, Jichen Li and Sumeet Kumar Singh.

\section{7. Funding}

519 We would like to acknowledge Canada Foundation for Innovation (John Evans Leadership Fund 520 [32860]), Alberta Livestock and Meat Agency Ltd. (Alberta Agriculture and Forestry 521 Innovation Program [2016F034R]), and Natural Sciences and Engineering Research Council of 522 Canada (Discovery Grant [2018-05717]) for their financial support of this research.

\section{$523 \quad$ 8. Conflict of interest}

524 The authors declare that they have no conflict of interest. 


\section{References}

526

527

528

529

530

531

532

533

534

535

536

537

538

539

540

541

542

543

544

545

546

547

548

Abalos D, Brown SE, Vanderzaag AC, Gordon RJ, Dunfield KE, Wagner-Riddle C (2016) Micrometeorological measurements over 3 years reveal differences in $\mathrm{N}_{2} \mathrm{O}$ emissions between annual and perennial crops. Global Change Biol 22(3):1244-1255

Blagodatskaya E, Blagodatsky S, Anderson T, Kuzyakov Y (2007) Priming effects in Chernozem induced by glucose and $\mathrm{N}$ in relation to microbial growth strategies. Appl Soil Ecol 37(1-2):95-105

Blagodatskaya E, Kuzyakov Y (2008) Mechanisms of real and apparent priming effects and their dependence on soil microbial biomass and community structure: critical review. Biol Fertility Soils 45(2):115-131

Burton D, Li X, Grant C (2008) Influence of fertilizer nitrogen source and management practice on $\mathrm{N}_{2} \mathrm{O}$ emissions from two Black Chernozemic soils. Can J Soil Sci 88(2):219-227

Butterbach-Bahl K, Baggs EM, Dannenmann M, Kiese R, Zechmeister-Boltenstern S (2013) Nitrous oxide emissions from soils: how well do we understand the processes and their controls?. Philosophical transactions of the Royal Society of London Series B, Biological sciences 368(1621):20130122

Carter MR, Gregorich EG (2007) Soil sampling and methods of analysis. CRC Press, Florida

Chai LL, Hernandez-Ramirez G, Dyck M, Pauly D, Kryzanowski L, Middleton A, Powers L, Lohstraeter G, Werk D (2020) Can fertigation reduce nitrous oxide emissions from wheat and canola fields?. Sci Total Environ 745:141014

Chen R, Senbayram M, Blagodatsky S, Myachina O, Dittert K, Lin X, Blagodatskaya E, Kuzyakov Y (2014) Soil C and N availability determine the priming effect: microbial N mining and stoichiometric decomposition theories. Global Change Biol 20(7):2356-2367

Cheng W, Kuzyakov Y (2005) Root effects on decomposition of organic matter. Roots and Soil Management: Interactions Between Roots and Soil.Agronomy Monograph 48:119-143

Cheng W (1999) Rhizosphere feedbacks in elevated $\mathrm{CO}_{2}$. Tree Physiol 19(4-5):313-320

Congreves KA, Phan T, Farrell RE (2019) A new look at an old concept: using ${ }^{15} \mathrm{~N}_{2} \mathrm{O}$ isotopomers to understand the relationship between soil moisture and $\mathrm{N}_{2} \mathrm{O}$ production pathways. Soil 5(2):265-274 
554 Curtin D, Beare MH, Scott CL, Hernandez-Ramirez G, Meenken ED (2014) Mineralization of 555 soil carbon and nitrogen following physical disturbance: a laboratory assessment. Soil Sci Soc 556 Am J 78(3):925-935

557 Curtin D, Beare MH, Hernandez-Ramirez G (2012) Temperature and moisture effects on 558 microbial biomass and soil organic matter mineralization. Soil Sci Soc Am J 76(6):2055-2067

559 Daly EJ, Hernandez-Ramirez $\mathrm{G}$ (2020) Sources and priming of soil $\mathrm{N}_{2} \mathrm{O}$ and $\mathrm{CO}_{2}$ production: 560 Nitrogen and simulated exudate additions. Soil Biol Biochem 149:107942

561 Davidson EA (1991) Fluxes of nitrous oxide and nitric oxide from terrestrial ecosystems. 562 Microbial production and consumption of greenhouse gases: methane, nitrogen oxides, and 563 halomethanes.:219-235

564 Easterling DR, Arnold J, Knutson T, Kunkel K, LeGrande A, Leung LR, Vose R, Waliser D, 565 Wehner M (2017) Precipitation change in the United States. In: Wuebbles DJ, Fahey DW, 566 Hibbard KA, Dokken DJ, Stewart BC, and Maycock TK(eds) Climate Science Special Report: 567 Fourth National Climate Assessment, Volume I. U.S. Global Change Research Program, 568 Washington, DC, pp 207-230

569 Gan Y, Liang B, Liu L, Wang X, McDonald C (2011) C: N ratios and carbon distribution profile 570 across rooting zones in oilseed and pulse crops. Crop and Pasture Science 62(6):496-503

571 Ginting D, Kessavalou A, Eghball B, Doran JW (2003) Greenhouse gas emissions and soil 572 indicators four years after manure and compost applications. J Environ Qual 32(1):23-32

573 Goldberg SD, Muhr J, Borken W, Gebauer G (2008) Fluxes of climate-relevant trace gases 574 between a Norway spruce forest soil and atmosphere during repeated freeze-thaw cycles in 575 mesocosms. Journal of Plant Nutrition and Soil Science 171(5):729-739

576 Grant RF, Lin S, Hernandez-Ramirez G (2020) Modelling nitrification inhibitor effects on $\mathrm{N}_{2} \mathrm{O}$ 577 emissions after fall-and spring-applied slurry by reducing nitrifier $\mathrm{NH}_{4}{ }^{+}$oxidation rate.

578 Biogeosciences 17(7):2021-2039

579 Harris E, Henne S, Hüglin C, Zellweger C, Tuzson B, Ibraim E, Emmenegger L, Mohn J (2017) 580 Tracking nitrous oxide emission processes at a suburban site with semicontinuous, in situ 581 measurements of isotopic composition. Journal of Geophysical Research: Atmospheres 582 122(3):1850-1870

583 Högberg P (1997) Tansley review no. $95{ }^{15} \mathrm{~N}$ natural abundance in soil-plant systems. The New 584 Phytologist 137(2):179-203 
Hou A, Akiyama H, Nakajima Y, Sudo S, Tsuruta H (2000) Effects of urea form and soil moisture on $\mathrm{N}_{2} \mathrm{O}$ and $\mathrm{NO}$ emissions from Japanese Andosols. Chemosphere-Global Change Science 2(3-4):321-327

Hou AX, Chen GX, Wang ZP, Van Cleemput O, Patrick WH (2000) Methane and nitrous oxide emissions from a rice field in relation to soil redox and microbiological processes. Soil Sci Soc Am J 64(6):2180-2186

Intergovernmental Panel on Climate Change (2013) Climate Change 2013: The Physical Science Basis. Cambridge University Press, Cambridge and New York

Lin S, Hernandez-Ramirez G (2020) Nitrous oxide emissions from manured soils as a function of various nitrification inhibitor rates and soil moisture contents. Sci Total Environ 738:139669

Lin S, Hernandez-Ramirez G, Kryzanowski L, Wallace T, Grant R, Degenhardt R, Berger N, Lohstraeter G, Powers L (2017) Timing of Manure Injection and Nitrification Inhibitors Impacts on Nitrous Oxide Emissions and Nitrogen Transformations in a Barley Crop. Soil Sci Soc Am J 81(6):1595-1605

McKeague JA (1978) Manual on soil sampling and methods of analysis. Canadian Society of Soil Science, Ottawa

McKenzie R, Kryzanowski L, Pauly D (2013) Fertilizer Requirements of Irrigated Grain and Oilseed Crops. http://www1.agric.gov.ab.ca/\$department/deptdocs.nsf/all/agdex149. Accessed 11 December 2017

Ostrom PH, DeCamp S, Gandhi H, Haslun J, Ostrom NE (2021) The influence of tillage and fertilizer on the flux and source of nitrous oxide with reference to atmospheric variation using laser spectroscopy. Biogeochemistry:1-17

Parry M, Parry ML, Canziani O, Palutikof J, Van der Linden P, Hanson C (2007) Climate change 2007-impacts, adaptation and vulnerability. Cambridge University Press, Cambridge and New York

Paul K, Polglase P, O'connell A, Carlyle J, Smethurst P, Khanna P (2003) Defining the relation between soil water content and net nitrogen mineralization. Eur J Soil Sci 54(1):39-48

R Core Team (2014) R: A language and environment for statistical computing. http://www.Rproject.org/. Accessed 17 March 2015 
614 Roman-Perez CC, Hernandez-Ramirez G (2021) Sources and priming of $\mathrm{N}_{2} \mathrm{O}$ production across 615 a range of moisture contents in a soil with high organic matter. Journal of Environmental Quality 616 50(1):94-109

617 Ruser R, Flessa H, Russow R, Schmidt G, Buegger F, Munch J (2006) Emission of $\mathrm{N}_{2} \mathrm{O}, \mathrm{N}_{2}$ and $618 \mathrm{CO}_{2}$ from soil fertilized with nitrate: effect of compaction, soil moisture and rewetting. Soil Biol 619 Biochem 38(2):263-274

620 Soil Classification Working Group (1998) The Canadian system of soil classification. NRC 621 Research Press, Ottawa

622 Stanford G, Epstein E (1974) Nitrogen Mineralization-Water Relations in Soils 1. Soil Sci Soc 623 Am J 38(1):103-107

624 Sutka RL, Ostrom NE, Ostrom PH, Breznak JA, Gandhi H, Pitt AJ, Li F (2006) Distinguishing 625 nitrous oxide production from nitrification and denitrification on the basis of isotopomer 626 abundances. Appl Environ Microbiol 72(1):638-644

627 Thilakarathna SK, Hernandez-Ramirez G (2021) How does Management Legacy, Nitrogen 628 Addition and Nitrification Inhibition Impact Soil Organic Matter Priming and Nitrous Oxide 629 Production?. Journal of Environmental Quality 20(1):78-93

630 Thilakarathna SK, Hernandez-Ramirez G, Puurveen D, Kryzanowski L, Lohstraeter G, Powers 631 L, Quan N, Tenuta M (2020) Nitrous oxide emissions and nitrogen use efficiency in wheat: N 632 fertilization timing and formulation, soil N, and weather effects. Soil Sci Soc Am J 84(6):19106331927

634 Toyoda S, Yano M, Nishimura S, Akiyama H, Hayakawa A, Koba K, Sudo S, Yagi K, Makabe 635 A, Tobari Y (2011) Characterization and production and consumption processes of $\mathrm{N}_{2} \mathrm{O}$ emitted 636 from temperate agricultural soils determined via isotopomer ratio analysis. Global Biogeochem 637 Cycles 25(2)

638 Toyoda S, Yoshida N (1999) Determination of nitrogen isotopomers of nitrous oxide on a 639 modified isotope ratio mass spectrometer. Anal Chem 71(20):4711-4718

640 Waechter H, Mohn J, Tuzson B, Emmenegger L, Sigrist MW (2008) Determination of $\mathrm{N}_{2} \mathrm{O}$ 641 isotopomers with quantum cascade laser based absorption spectroscopy. Optics Express 642 16(12):9239-9244

643 Wagner-Riddle C, Furon A, Mclaughlin NL, Lee I, Barbeau J, Jayasundara S, Parkin G, Von 644 Bertoldi P, Warland J (2007) Intensive measurement of nitrous oxide emissions from a corn- 
645 soybean-wheat rotation under two contrasting management systems over 5 years. Global Change 646 Biol 13(8):1722-1736

647 Wolf B, Zheng X, Brüggemann N, Chen W, Dannenmann M, Han X, Sutton MA, Wu H, Yao Z, 648 Butterbach-Bahl K (2010) Grazing-induced reduction of natural nitrous oxide release from 649 continental steppe. Nature 464(7290):881-884

650 Wu X, Brüggemann N, Gasche R, Shen Z, Wolf B, Butterbach-Bahl K (2010) Environmental 651 controls over soil-atmosphere exchange of $\mathrm{N}_{2} \mathrm{O}, \mathrm{NO}$, and $\mathrm{CO}_{2}$ in a temperate Norway spruce 652 forest. Global Biogeochem Cycles 24(2)

653 Yamamoto A, Akiyama H, Nakajima Y, Hoshino YT (2017) Estimate of bacterial and fungal $654 \mathrm{~N}_{2} \mathrm{O}$ production processes after crop residue input and fertilizer application to an agricultural 655 field by ${ }^{15} \mathrm{~N}$ isotopomer analysis. Soil Biol Biochem 108:9-16

656 Yanai Y, Hirota T, Iwata Y, Nemoto M, Nagata O, Koga N (2011) Accumulation of nitrous 657 oxide and depletion of oxygen in seasonally frozen soils in northern Japan-Snow cover 658 manipulation experiments. Soil Biol Biochem 43(9):1779-1786

659 Zimmerman AR, Gao B, Ahn M (2011) Positive and negative carbon mineralization priming 660 effects among a variety of biochar-amended soils. Soil Biol Biochem 43(6):1169-1179 


\section{Tables}

663 Table 1. Soil physical and chemical properties at the $\mathbf{0 - 1 5} \mathrm{cm}$ depth increment of the soils 664 with (SW) and without (CT) history of liquid manure injections. Note that only organic 665 carbon showed a magnitude difference between these two soil managements, with SW 666 slightly higher than CT $(P>0.05)$.

\begin{tabular}{|c|c|c|c|c|c|c|}
\hline \multicolumn{7}{|l|}{ Soil properties } \\
\hline Classification $\dagger$ & \multicolumn{6}{|c|}{ Black Chernozem } \\
\hline Bulk density $\left(\mathrm{g} \mathrm{cm}^{-3}\right)$ & & & 1.11 & \pm 0.06 & & \\
\hline $\mathrm{pH}$ & & & 6.1 & \pm 0.2 & & \\
\hline Texture & \multicolumn{6}{|c|}{ Clay } \\
\hline $\operatorname{Clay}(\%)$ & & & 47.0 & \pm 1.2 & & \\
\hline $\operatorname{Silt}(\%)$ & & & 36.0 & \pm 0.3 & & \\
\hline \multirow[t]{2}{*}{ Sand(\%) } & & & 17.0 & \pm 1.0 & & \\
\hline & \multicolumn{3}{|c|}{ SW } & \multicolumn{3}{|c|}{$\mathrm{CT}$} \\
\hline Organic C $\left(\mathrm{g} \mathrm{C} \mathrm{kg}^{-1}\right)$ & 63.7 & \pm & $5.0 \%$ & 61.6 & \pm & 4.3 \\
\hline Total N ( $\left.\mathrm{g} \mathrm{N} \mathrm{kg}^{-1}\right)$ & 5.9 & \pm & 0.3 & 5.9 & \pm & 0.4 \\
\hline
\end{tabular}

$667 \dagger$ Based on the Canadian System of Soil Classification (Soil Classification Working Group 1998). $668 \$$ Standard error of the mean.

669 
670 Table 2. P-values of ANOVA models for soil $\mathrm{NH}_{4}{ }^{+}$and $\mathrm{NO}_{3}{ }^{-}$concentrations as well as

671 cumulative $\mathrm{N}_{2} \mathrm{O}$ and $\mathrm{CO}_{2}$ emissions after thawing (Days 56-86).

\begin{tabular}{|c|c|c|c|c|c|c|c|}
\hline Experimental factor & $\mathrm{NH}_{4}{ }^{+}$ & $\mathrm{NO}_{3}^{-}$ & $\begin{array}{r}\text { Cumulative } \\
\qquad \mathrm{N}_{2} \mathrm{O}\end{array}$ & $\begin{array}{r}\text { SOM- } \\
\text { derived } \\
\mathrm{N}_{2} \mathrm{O}\end{array}$ & $\begin{array}{r}\text { Urea- } \\
\text { derived } \\
\mathrm{N}_{2} \mathrm{O}\end{array}$ & $\begin{array}{r}\text { Primed } \\
\mathrm{N}_{2} \mathrm{O}\end{array}$ & $\begin{array}{r}\text { Cumulative } \\
\mathrm{CO}_{2}\end{array}$ \\
\hline $\begin{array}{l}\text { History of manure } \\
\text { application (Soil) }\end{array}$ & n.s. & 0.002 & 0.006 & 0.002 & n.s. & n.s. & n.s. \\
\hline Water content (Water) $)^{\ddagger}$ & n.s. & 0.035 & $<0.001$ & $<0.001$ & n.s. & n.s. & $<0.001$ \\
\hline $\begin{array}{l}\text { Nitrogen addition } \\
(\text { Nitrogen })^{\S}\end{array}$ & n.s. & $<0.001$ & $<0.001$ & 0.022 & N/A & N/A & n.s. \\
\hline Soil $\times$ Water & n.s. & 0.042 & n.s. & n.s. & n.s. & n.s. & n.s. \\
\hline Soil $\times$ Nitrogen & n.s. & n.s. & n.s. & n.s. & N/A & $\mathrm{N} / \mathrm{A}$ & n.s. \\
\hline Water $\times$ Nitrogen & n.s. & n.s. & n.s. & n.s. & N/A & $\mathrm{N} / \mathrm{A}$ & n.s. \\
\hline Soil $\times$ Water $\times$ Nitrogen & n.s. & n.s. & n.s. & n.s. & N/A & $\mathrm{N} / \mathrm{A}$ & n.s. \\
\hline
\end{tabular}

$672 \dagger$ History of manure application factor included two levels: soils with spring manure (SW) and

673 without a history of liquid manure injections (field control, CT).

$674 \ddagger$ Water content factor included three levels: Low, Medium, and High water contents.

$675 \S$ Nitrogen factor included two levels: with and without urea additions. Soils without urea are

676 also referred as controls.

677 
678 Table 3. The ${ }^{15} \mathrm{~N}$ isotope discrimination $[\varepsilon$, mean $\pm \mathrm{SE}(\%), n=3]$ of soil $\mathrm{N}_{2} \mathrm{O}$ emitted 1 day 679 after thawing (the time of peak emissions in the study) relative to the soil $\mathbf{N}$ pool in both 680 field control (CT) and manure-treated (SW) soils at various water contents. Calculation 681 based on Eq. [13].

\begin{tabular}{lccccccc}
\hline Soil & Water content & \multicolumn{3}{c}{ Soil $\times$ Water Content } & \multicolumn{3}{c}{ Soil } \\
\hline & Low & -10.19 & \pm & 11.21 & & & \\
CT & Medium & -7.68 & \pm & 2.76 & -11.73 & \pm & 3.86 \\
& High & -17.34 & \pm & 4.46 & & & \\
& Low & -18.78 & \pm & 3.60 & & & \\
& Medium & -15.45 & \pm & 4.94 & -15.26 & \pm & 2.30 \\
SW & High & -11.56 & \pm & 3.65 & & & \\
\hline
\end{tabular}

682

683 
Figures

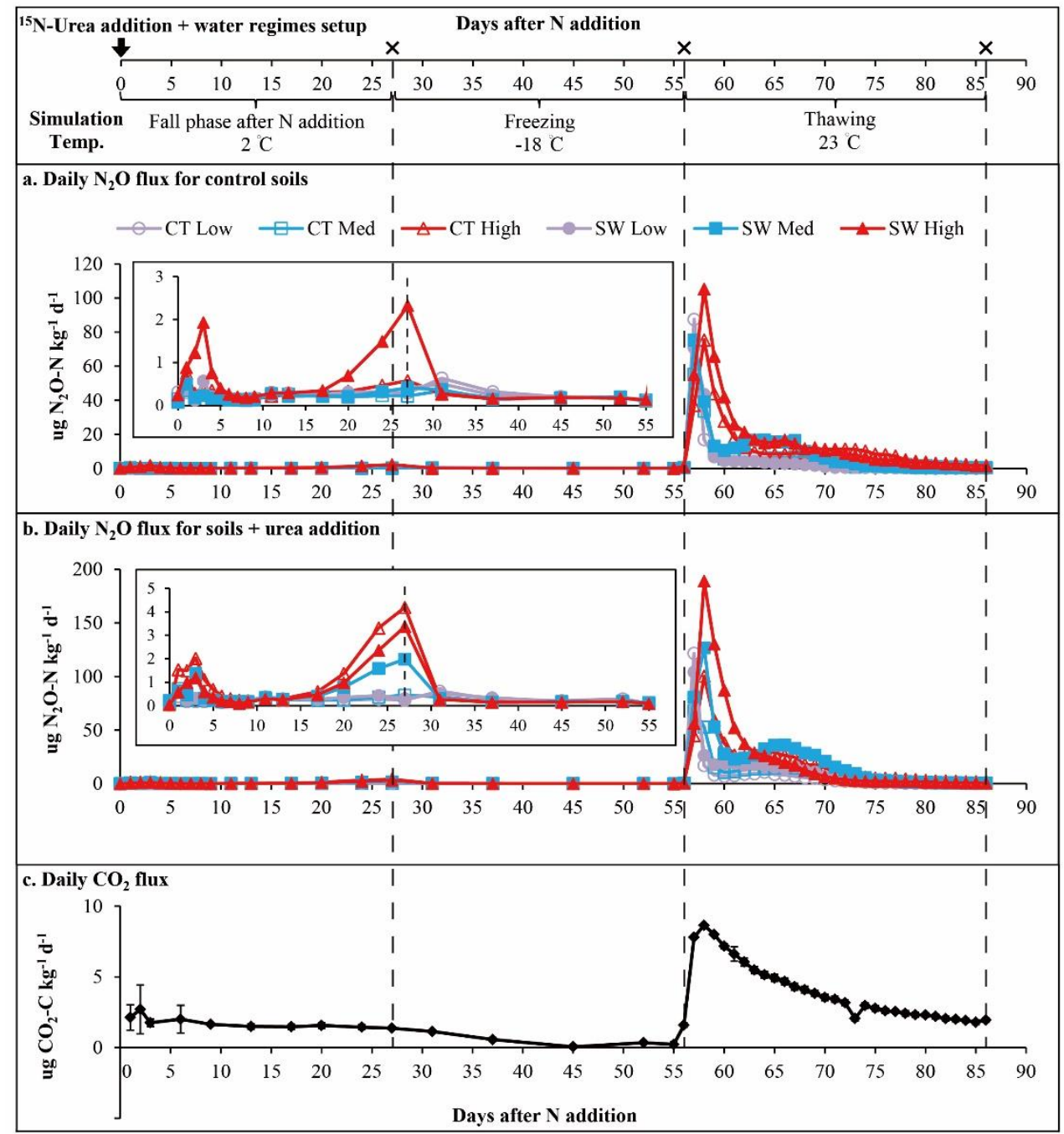

Fig. 1. Daily nitrous oxide $\left(\mathrm{N}_{2} \mathrm{O}\right)$ and carbon dioxide $\left(\mathrm{CO}_{2}\right)$ fluxes from soils over the entire experiment. In the case of $\mathrm{N}_{2} \mathrm{O}$, fluxes are shown in two separate panels as subsets (a) without and (b) with added urea. Fluxes of $\mathrm{CO}_{2}$ are averaged across all treatment combinations. SW and CT stand for soils with and without a history of manure additions, 
respectively. Low, Med, and High correspond to moisture regimes where Med stands for Medium. Error bars correspond to one standard error of the mean. 


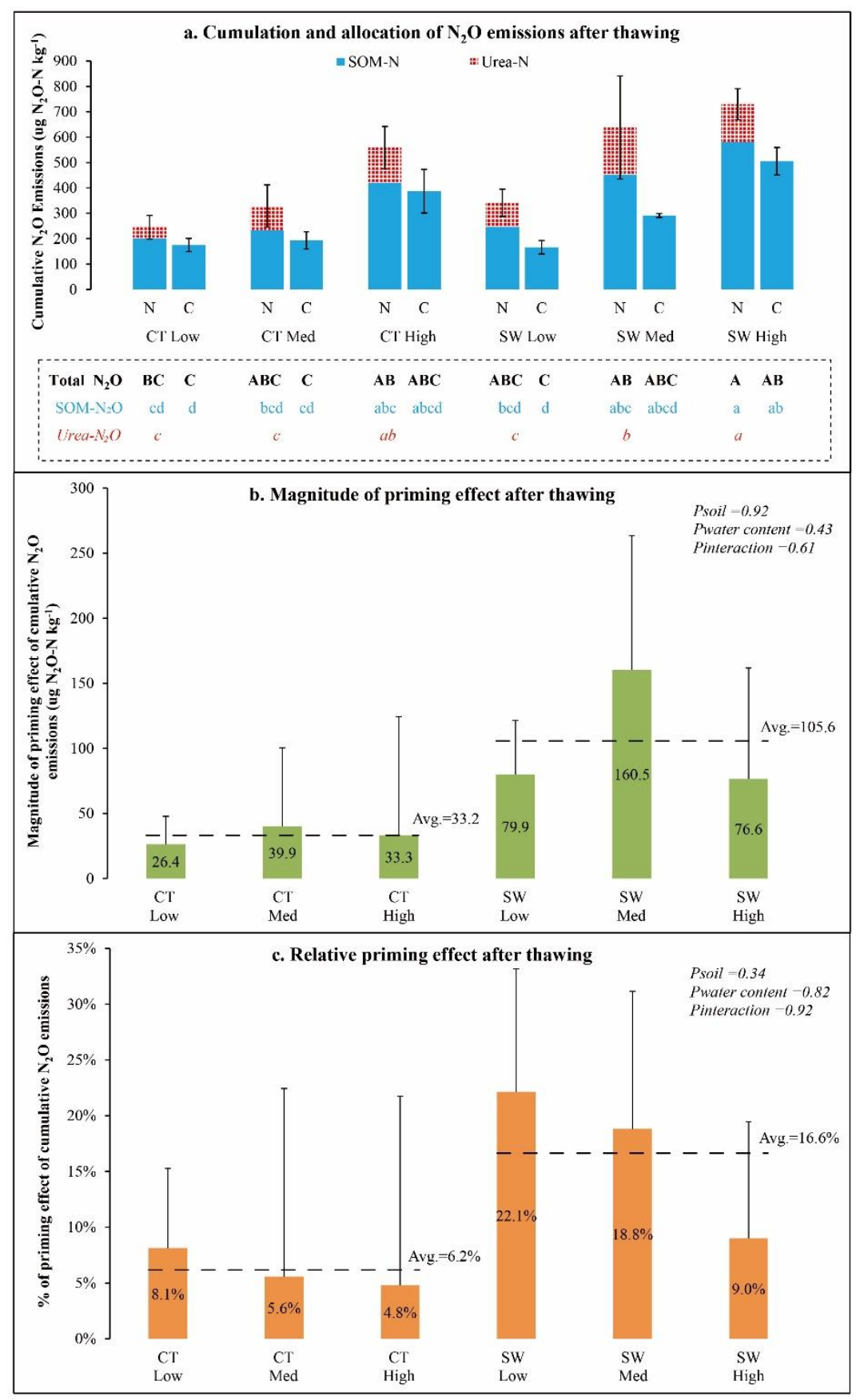

Fig. 2. (a) Cumulative $\mathrm{N}_{2} \mathrm{O}$ emissions allocated to urea and soil organic matter (SOM) sources, (b) magnitude priming and (c) relative priming caused by urea addition following soil thawing. SW and CT stand for soils with and without a history of manure additions, 
respectively. Low, Med, and High correspond to moisture regimes where Med stands for Medium. In Panel a, $\mathrm{N}$ and $\mathrm{C}$ acronyms correspond to the urea- $\mathrm{N}$ addition treatment and the zero-N addition (control) treatment, respectively. In Panel a, different letters indicate significant difference in total cumulative $\mathrm{N}_{2} \mathrm{O}$ (uppercase), SOM-derived $\mathrm{N}_{2} \mathrm{O}$ (lowercase) and urea-derived (italic) $\mathrm{N}_{2} \mathrm{O}$ emissions after thawing $(P<0.05)$. In Panels $b$ and $\mathrm{c}, \mathrm{N}_{2} \mathrm{O}$ primings were respectively shown as magnitudes and also in relative basis as percentages of the total fluxes (shown in Panel a) of soil pots receiving urea. Error bars correspond to one standard error. 


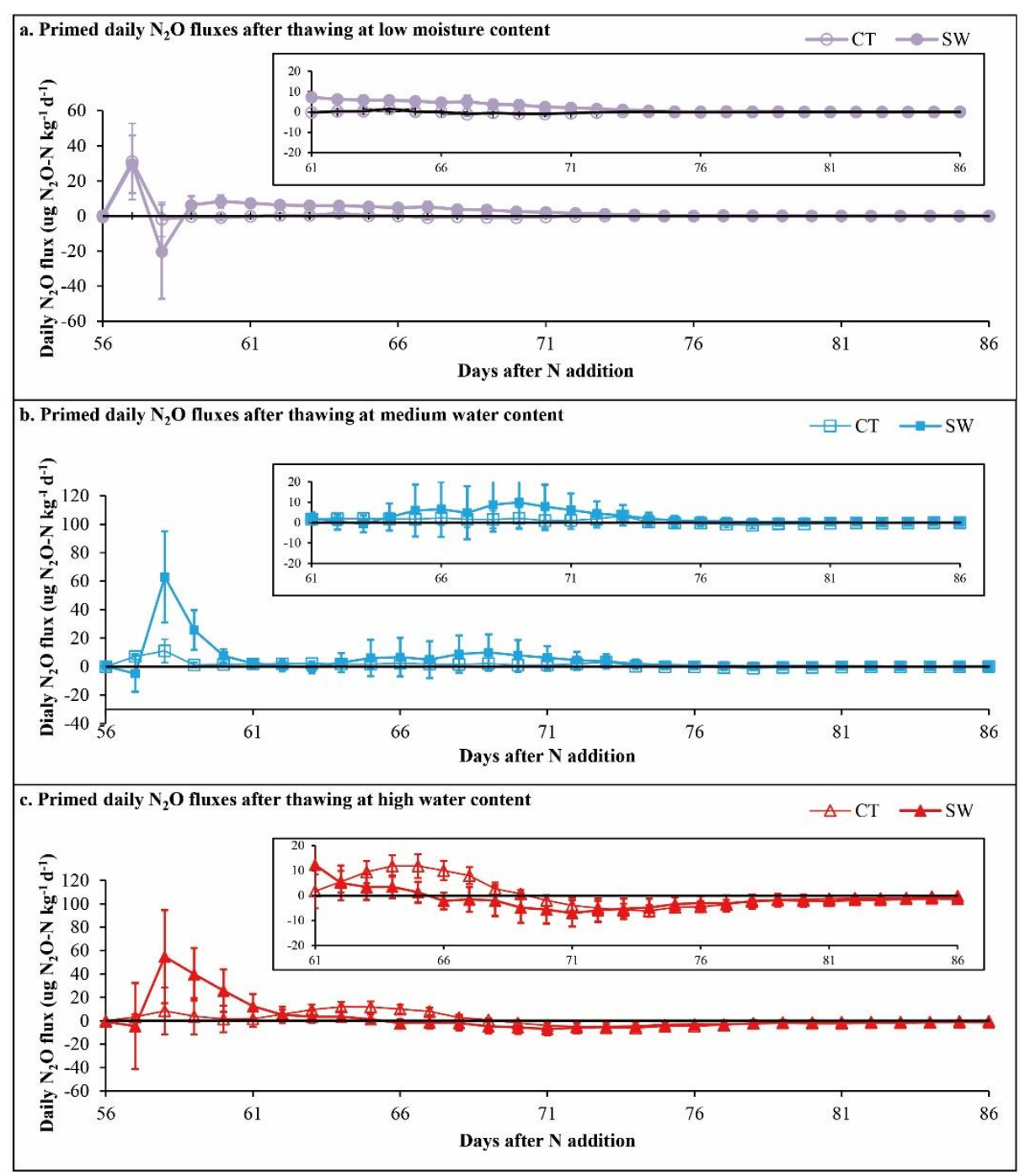

Fig. 3. Primed daily $\mathrm{N}_{2} \mathrm{O}$ fluxes following soil thawing. SW and CT stand for soils with and without a history of manure additions, respectively. Low, Med, and High correspond to moisture regimes where Med stands for Medium. Positive and negative primed daily $\mathrm{N}_{2} \mathrm{O}$ fluxes represent positive and negative priming effects, respectively. Error bars correspond to one standard error of the mean. 


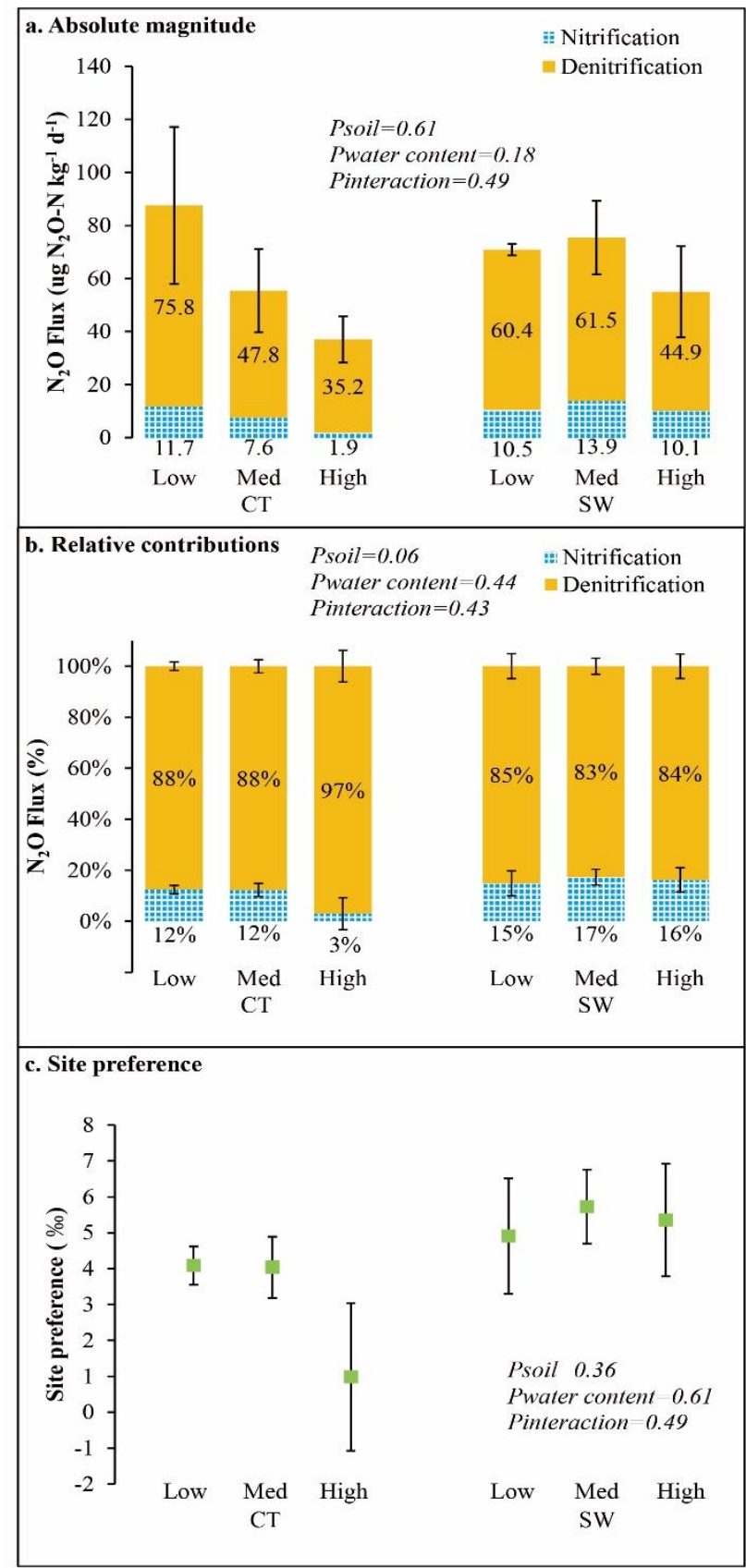

Fig. 4. (a) Magnitude and (b) relative contributions of nitrification and denitrification, as well as (c) site preference for the $\mathrm{N}_{2} \mathrm{O}$ fluxes emitted 1 day after thawing (Day 57 of the 
experiment). SW and CT stand for soils with and without a history of manure additions, respectively. Low, Med, and High correspond to moisture regimes where Med stands for Medium. In Panels a and b, numbers in the columns are respectively the flux magnitude and percentage of $\mathrm{N}_{2} \mathrm{O}$ emissions produced via denitrification or nitrification. Error bars correspond to standard error of the mean. 


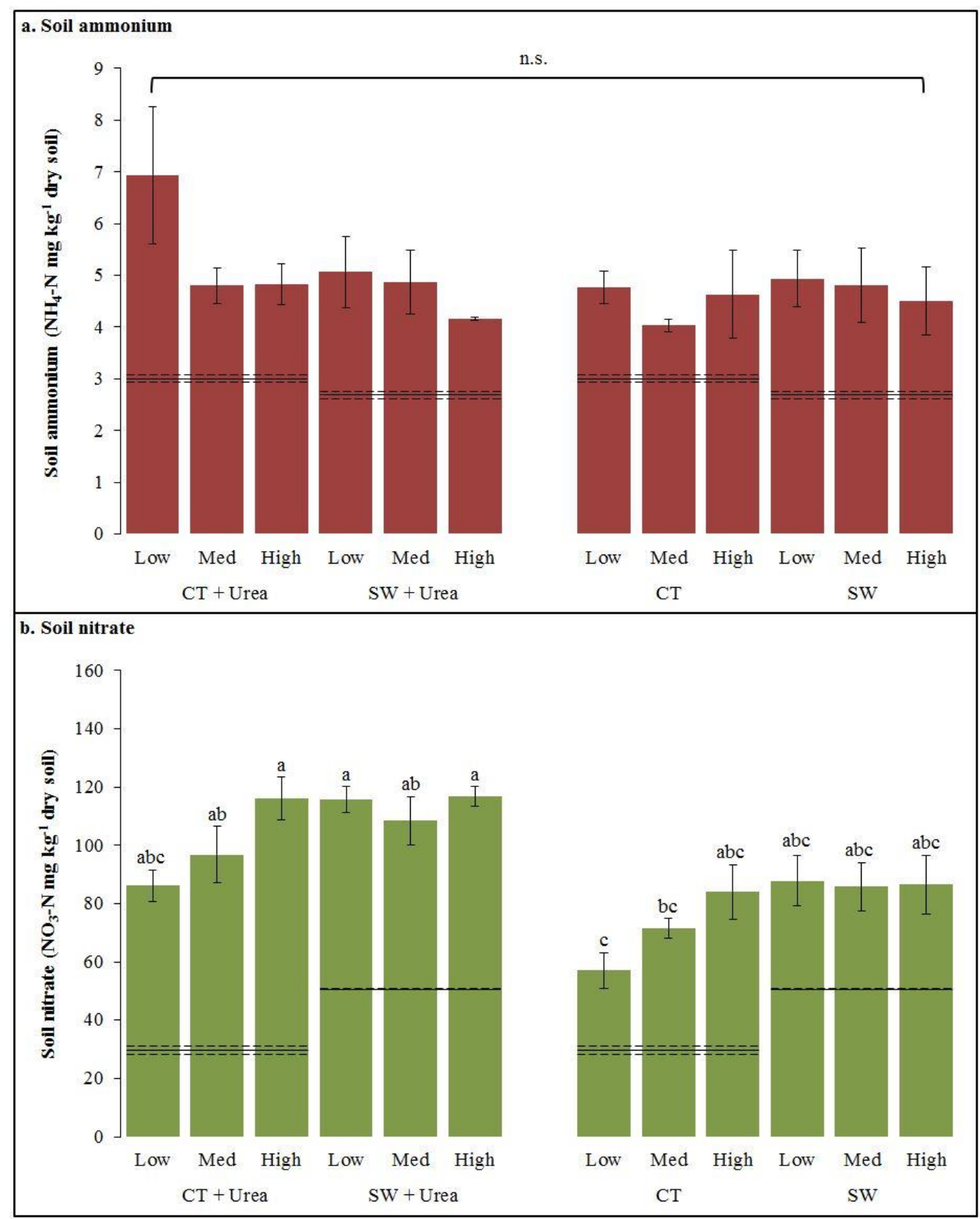

Fig. 5. Soil (a) ammonium and (b) nitrate concentrations at the end of the experiment for the soils with (SW) and without (CT) history of manure additions at Low, Medium (Med) and High moisture regimes. Horizontal lines (with one standard error) across moisture 
contents are the concentrations of (a) ammonium and (b) nitrate of the two soils at the beginning of the experiment (prior to urea addition and establishment of the three moisture regimes). Different letters indicate significant differences among treatment combinations $(P<\mathbf{0 . 0 5})$. Error bars correspond to one standard error of the mean. n.s. = not significant. 
Figures

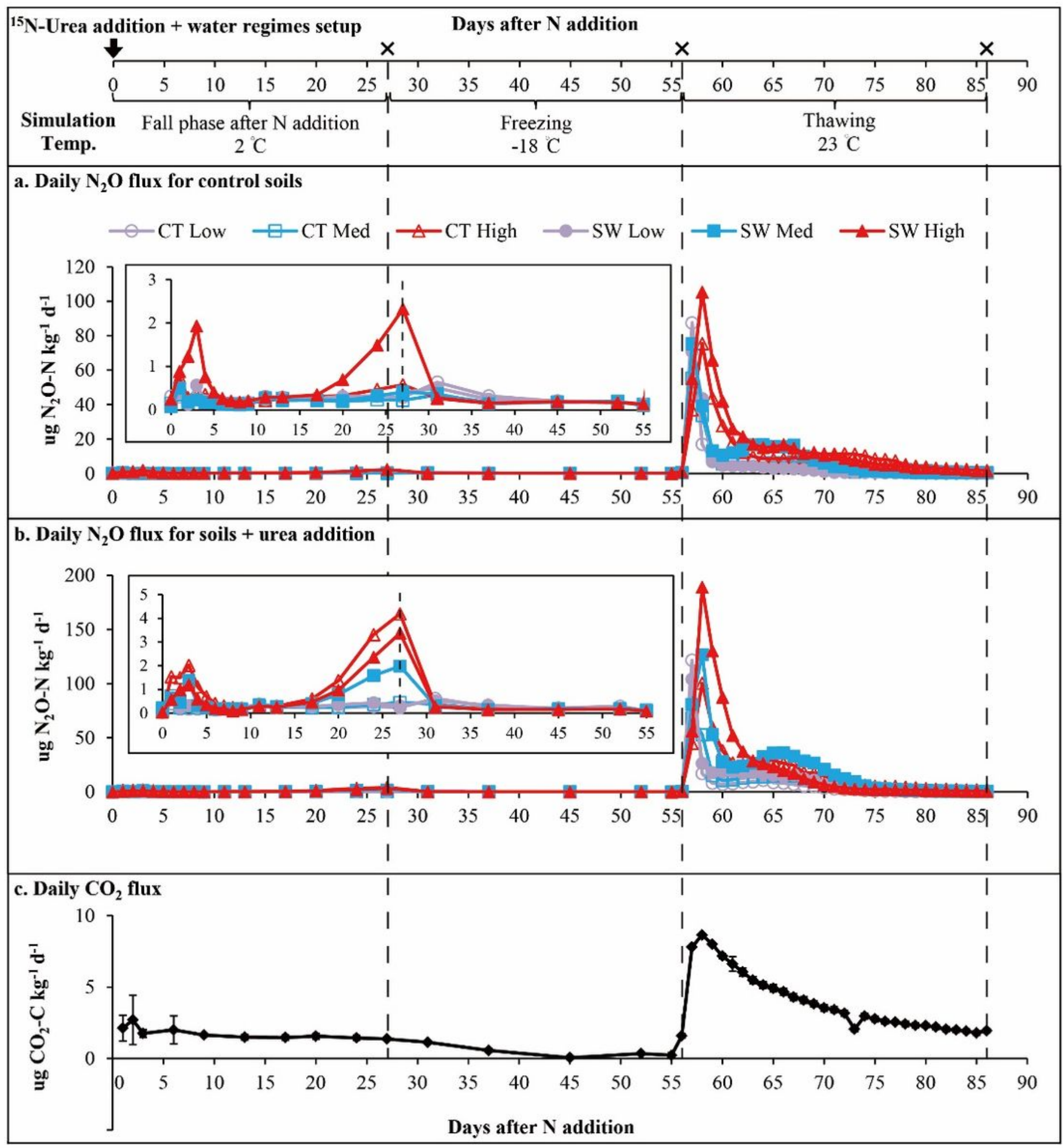

Figure 1

Daily nitrous oxide (N2O) and carbon dioxide (CO2) fluxes from soils over the entire experiment. In the case of N2O, fluxes are shown in two separate panels as subsets (a) without and (b) with added urea. Fluxes of $\mathrm{CO} 2$ are averaged across all treatment combinations. SW and CT stand for soils with and 
without a history of manure additions, respectively. Low, Med, and High correspond to moisture regimes where Med stands for Medium. Error bars correspond to one standard error of the mean.
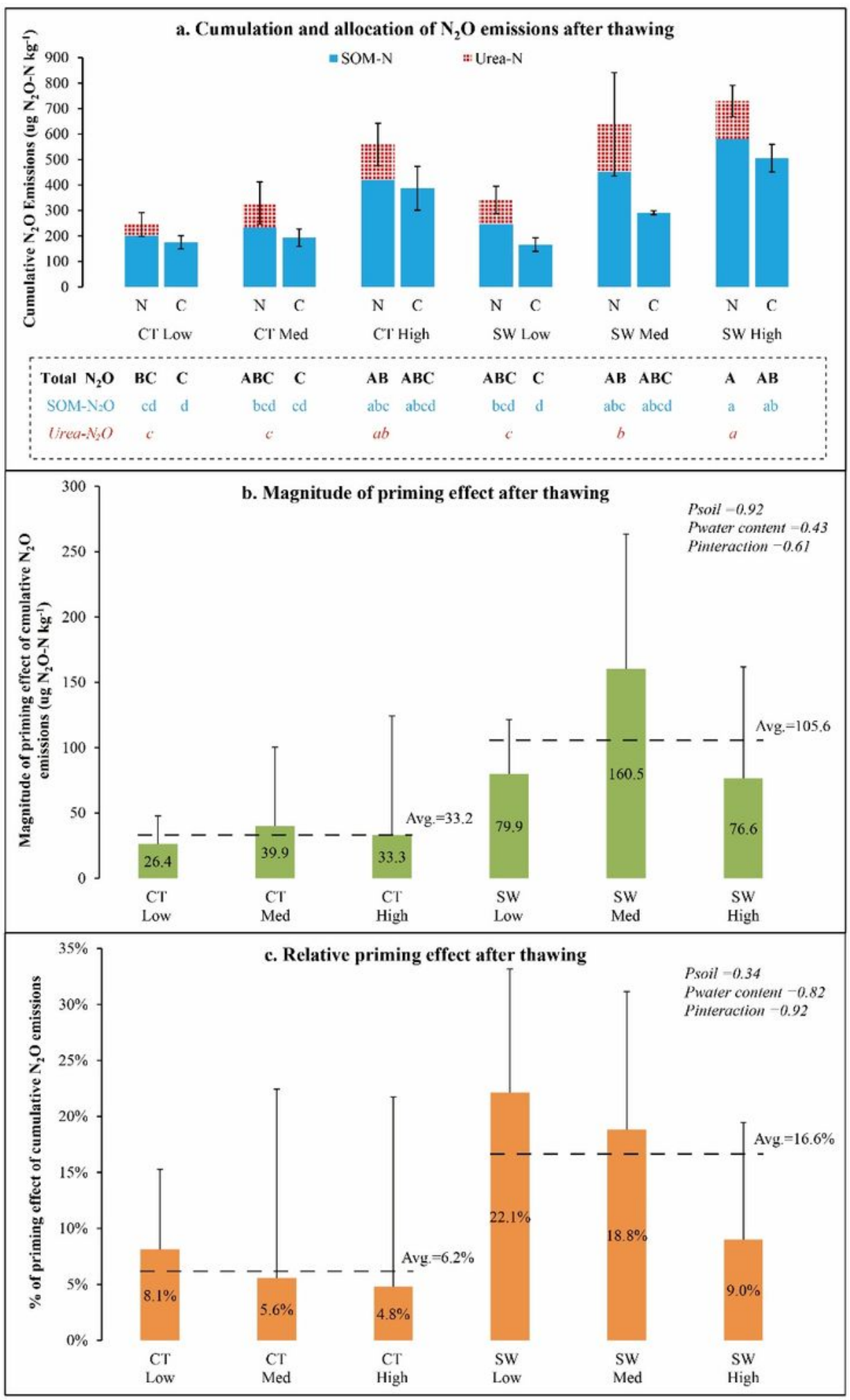

Figure 2

(a) Cumulative $\mathrm{N} 2 \mathrm{O}$ emissions allocated to urea and soil organic matter (SOM) sources, (b) magnitude priming and (c) relative priming caused by urea addition following soil thawing. SW and CT stand for soils with and without a history of manure additions, respectively. Low, Med, and High correspond to 
moisture regimes where Med stands for Medium. In Panel a, N and C acronyms correspond to the urea-N addition treatment and the zero- $\mathrm{N}$ addition (control) treatment, respectively. In Panel a, different letters indicate significant difference in total cumulative N2O (uppercase), SOM-derived N2O (lowercase) and urea-derived (italic) N2O emissions after thawing $(P<0.05)$. In Panels b and c, N2O primings were respectively shown as magnitudes and also in relative basis as percentages of the total fluxes (shown in Panel a) of soil pots receiving urea. Error bars correspond to one standard error.

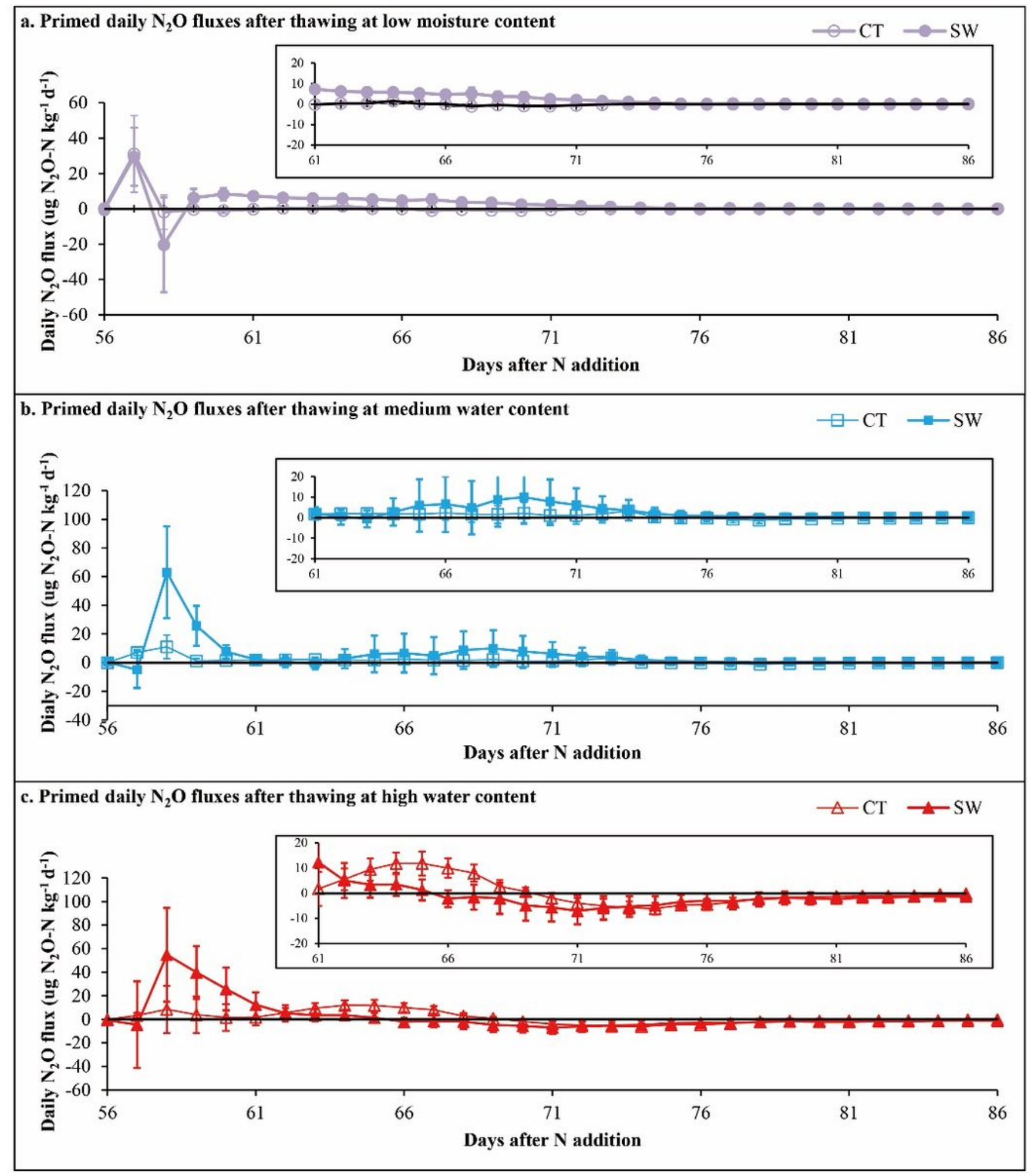

Figure 3 
Primed daily N2O fluxes following soil thawing. SW and CT stand for soils with and without a history of manure additions, respectively. Low, Med, and High correspond to moisture regimes where Med stands for Medium. Positive and negative primed daily N2O fluxes represent positive and negative priming effects, respectively. Error bars correspond to one standard error of the mean.

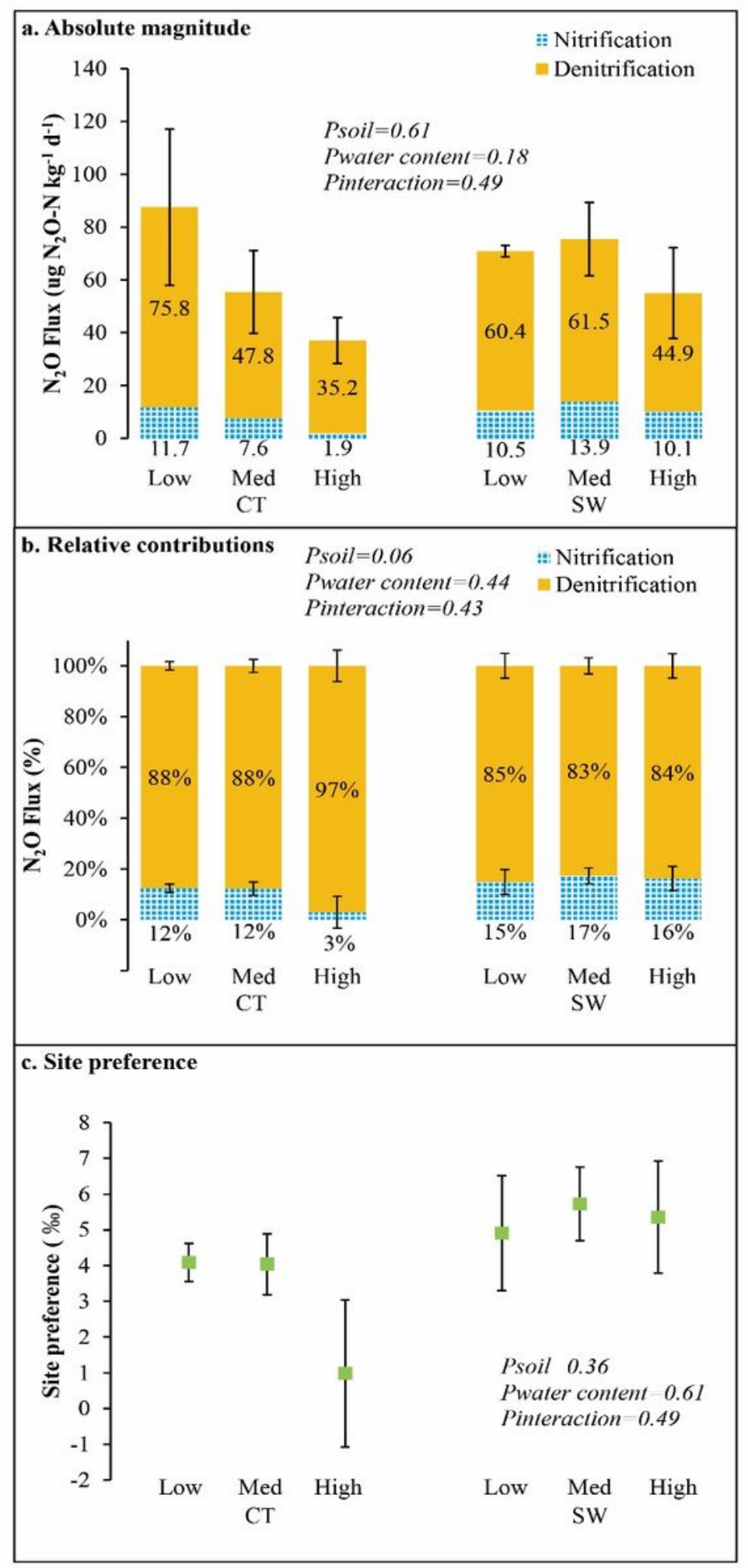

Figure 4 
(a) Magnitude and (b) relative contributions of nitrification and denitrification, as well as (c) site preference for the $\mathrm{N} 2 \mathrm{O}$ fluxes emitted 1 day after thawing (Day 57 of the experiment). SW and CT stand for soils with and without a history of manure additions, respectively. Low, Med, and High correspond to moisture regimes where Med stands for Medium. In Panels a and b, numbers in the columns are respectively the flux magnitude and percentage of N2O emissions produced via denitrification or nitrification. Error bars correspond to standard error of the mean.

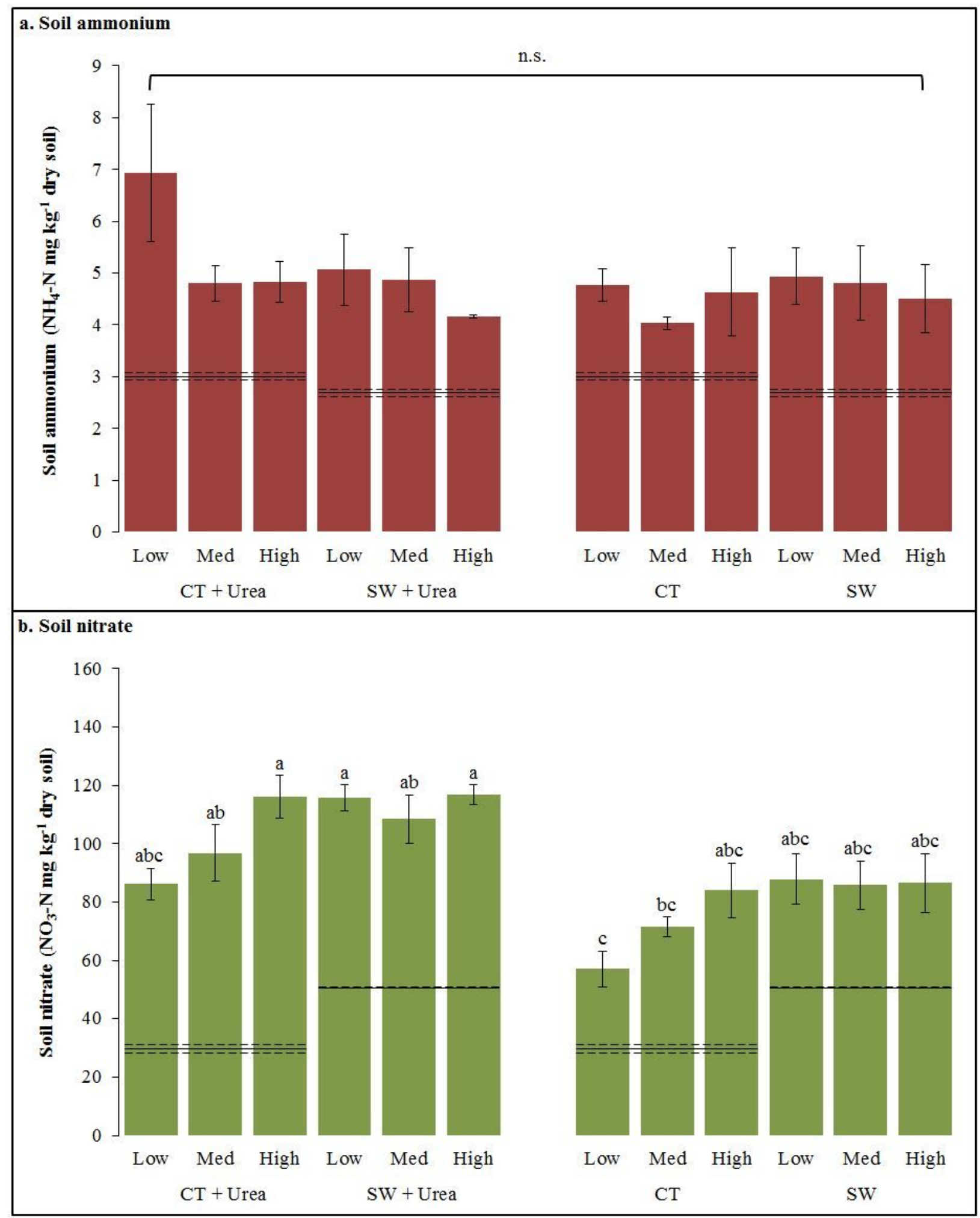

Figure 5 
Soil (a) ammonium and (b) nitrate concentrations at the end of the experiment for the soils with (SW) and without (CT) history of manure additions at Low, Medium (Med) and High moisture regimes. Horizontal lines (with one standard error) across moisture contents are the concentrations of (a) ammonium and (b) nitrate of the two soils at the beginning of the experiment (prior to urea addition and establishment of the three moisture regimes). Different letters indicate significant differences among treatment combinations $(P<0.05)$. Error bars correspond to one standard error of the mean. n.s. $=$ not significant.

\section{Supplementary Files}

This is a list of supplementary files associated with this preprint. Click to download.

- SupplementarydatamesocosmwoCopyghr.docx 